\title{
Fen Eğitiminde Kullanılan Dijital Hikâyelerin Öğretmen Adaylarının Akademik Başarısı, Sayısal Yetkinlik Durumları ve Sorgulama Becerileri Üzerindeki Etkisi
}

\author{
The Effect of Digital Stories Used in Science Education on Academic \\ Achievement, Digital Empowerment and Inquiry Skills of Teacher Candidates \\ Agah Tuğrul KORUCU ${ }^{1}$
}

Öz

\begin{abstract}
Araştırmanın amacı laboratuvar uygulama dersinde dijital hikâye geliştirme ortamını kullanan biyoloji öğretmeni adaylarının akademik başarıları, sayısal yetkinlik durumları ve sorgulayıcı öğrenme durumlarındaki değişimi ortaya koymaktır. Araştırmanın çalışma grubunu 2015-2016 eğitim-öğretim yılında, Necmettin Erbakan Üniversitesi, Ahmet Keleşoğlu Eğitim Fakültesi, Matematik ve Fen Bilimleri Eğitimi Bölümü, Biyoloji Eğitimi Anabilim Dalında 2.sınıfta öğrenimine devam eden 39 öğretmen adayı oluşturmaktadır. Araştırmada hem nicel hem de nitel yöntem benimsenmiş ve bu iki yöntem bir arada kullanılmıştır. Veri toplama aracı olarak araştırmacılar tarafından geliştirilen "Kişisel Bilgi Formu”, "Başarı Testi”, "Dijital Hikâye Geliştirme Ortamının Kullanımına Yönelik Yapılandırılmış Form" ile Aldan-Karademir ve Saraçoğlu (2013) tarafından geliştirilen "Sorgulama Becerileri Ölçeği" ve Akkoyunlu, Yılmaz Soylu ve Çağlar (2010) tarafından geliştirilen "Sayısal Yetkinlik Ölçeği”" kullanılmıştır. Araştırma kapsamında elde edilen nicel veriler SPSS 21.0 programı ile çözümlenmiştir. Araştırmanın nitel verilerinin analizinde ise içerik analizi yöntemi kullanılmıştır. Araştırmada Biyoloji öğretmeni adaylarının “Laboratuvar Uygulamaları" dersi kapsamında Web 2.0 teknolojileri ile desteklenmiş dijital hikâye geliştirme ortamını kullanmaları sonucunda, bu dijital hikayeler sayesinde öğretmen adaylarının akademik başarıları, sayısal yetkinlikleri ve sorgulama becerilerinde artış olduğuna yönelik bulgulara rastlanmıştır. Ayrıca yapılan görüşmeler sonucunda dijital hikayelerin, öğrencilerin öğrenme süreçleri ve teknoloji kullanımlarına yönelik olumlu yönde etkisinin bulunduğu yorumlarının çoğunlukta olduğu sonucuna ulaşılmıştır.
\end{abstract}

Anahtar Kelimeler: biyoloji, fen eğitimi, laboratuvar, öğretmen adayı, dijital hikâye, Web 2.0 teknolojileri.

\section{Abstract}

The aim of the study is to reveal the changes in academic achievement, digital empowerment status and inquiry learning skills of biology teacher candidates who use the digital story development environment in the laboratory practice course. The study group consisted of 39 teacher candidates in Necmettin Erbakan University, Ahmet Kelesoglu Faculty of Education, Department of Mathematics and Science Education, Biology Education Department in the 2015-2016 academic year. In the research, both quantitative and qualitative methods were adopted and used together. "Personal Information Form", "Success Test", "Structured Form for Use of Digital Story Development Environment" developed by the researchers as data collection tool were used. In addition, "Inquiry Skills Scale" was developed by Aldan-Karademir and Saraçoğlu (2013) and "Digital Empowerment Scale" was developed by Akkoyunlu, Yılmaz Soylu and Çağlar (2010) was used. The quantitative data obtained from the study were analyzed with SPSS 21.0 program. In the analysis of the qualitative data of the research, content analysis method was used. In the research, it was found that there was an increase in the academic achievement, numerical competence and questioning skills as a result of the use of digital story development environment supported by Web 2.0 technologies within the scope of "Laboratory Practices" course of Biology teacher candidates. As a result of the research, biology teacher candidates who use digital story development environment supported by Web 2.0 technologies in 'Laboratory Applications' course; there was an increase in academic achievement, numerical competence and questioning skills. In addition, as a result of the interviews, it has been concluded that digital stories have a very positive effect on students' learning processes and use of technology

Keywords: biology, science education, laboratory, teacher candidate, digital story, Web 2.0 technologies.

\footnotetext{
${ }^{1}$ Necmettin Erbakan Üniversitesi, Ahmet Keleşoğlu Eğitim Fakültesi, Bilgisayar ve Öğretim Teknolojileri Eğitimi Bölümü, Konya, Türkiye, https://orcid.org/00000002-8334-1526

Atıf / Citation: Korucu, A, T.(2020). Fen Eğitiminde Kullanılan Dijital Hikâyelerin Öğretmen Adaylarının Akademik Başarısı, Sayısal Yetkinlik Durumları ve Sorgulama Becerileri Üzerindeki Etkisi, Kastamonu Education Journal, 28(1), 352-370. doi:10.24106/kefdergi.3617
} 


\section{Extended Abstract}

Problem and Purpose: Recently, with the use of formal and informal environments in the process of learning and teaching supported by technological transformations communication and cooperation; digital transformations are considered as applications that provide new teaching methods to the students and that involve learners in their learning situations (Hung, Hwang and Huang, 2012; Lowenthal, 2009; Lowenthal and Dunlap, 2010). Research in the literature suggests that digital stories improve students' achievements, develop high-level thinking skills such as decision-making, problem-solving, and critical thinking and inquiring and strengthen skills such as technology competence and digital empowerpent (Chung, 2007; Kajder, 2004; Lowenthal and Dunlap 2010; Robin, 2008; Sadik, 2008; Yang and Wu, 2012; Ware, 2006). On the other hand, in order to educate individuals who can use technology effectively, critically look, solve problems and question in the field of science education in our country, it is clear that teachers need to be educated and be supported with these skills. From this point of view, the effects of digital stories supported by Web 2.0 technologies on the academic achievement, digital empowerment and inquiry skills of biology teacher candidates were investigated.

Method: The study group consisted of 39 teacher candidates in Necmettin Erbakan University, Ahmet Kelesoglu Faculty of Education, Department of Mathematics and Science Education, Biology Education Department in the 2015-2016 academic year. In the research, both quantitative and qualitative methods were adopted and used together. "Personal Information Form", "Success Test", "Structured Form for Use of Digital Story Development Environment" developed by the researchers as data collection tool were used. In addition, "Inquiry Skills Scale" was developed by Aldan-Karademir and Saraçoğlu (2013) and “Digital Empowerment Scale” was developed by Akkoyunlu, Yılmaz Soylu and Çağlar (2010) was used. The study covers a period of 14 weeks. Firstly, 'Personal Information Form', 'Success Test', 'Inquiry Skills Scale' and 'Digital Empowerment Scale' was applied to the experimental and control group students. Then, in a 10-week period, experimental group students were taught in a learning environment designed with the support of Web 2.0 technologies, and control group students were instructed in the process of 'Laboratory Practice' with traditional methods. After the application process again, 'Success Test', 'Inquiry Skills Scale' and 'Digital Empowerment Scale' were applied. Finally, interviews were conducted with 'Structured Form for Use of Digital Story Development Environment' in order to elaborate the experience of the experimental group students in the digital story development process. The quantitative data obtained from the research were analyzed by using the computerized statistical package program. In the qualitative analysis of the research, data were analyzed by using the content analysis method.

Finding: At the end of the research, a meaningful difference was determined between the success scores [t $(37)=0.02$, $p<.05]$, digital empowerment scores [t $(37)=0.08, p<.05]$ and the inquiry skills scores $[t(37)=0.11, p<.05]$ of the experimental and control groups posttest. This result shows that the digital story development process develops students' achievements, digital empowerment and inquiry skills. On the other hand, as a result of the interviews conducted in order to determine the positive and negative aspects of digital stories, and to determine the students' achievements and difficulties in the digital story creation process, it was determined that the students had both positive and negative thoughts about the learning process and the use of technology throughout the digital story activity. To gain the ability to search information and gain access to information $(N=17)$, to give the ability to use time effectively $(N=14)$, to increase motivation $(N=13)$, to gain internet usage skills $(N=12)$, to make their learning more permanent $(N=11)$ and the easier access to content $(\mathrm{N}=10)$ through digital stories are the most pronounced positive characteristics determined by students. On the other hand, students expressed the negative effects of using time effectively $(N=6)$ and interest in the course ( $N=4)$. In the interviews, the difference between the digital stories and the other activities was emphasized as entertaining process $(\mathrm{N}=15)$, providing a technologically supported environment $(\mathrm{N}=14)$, being interesting $(\mathrm{N}=4)$ and providing more permanent learning $(\mathrm{N}=4)$.

Research has shown that developing a digital story in the field of science has the benefits of increasing success, facilitating learning, providing technology competence and digital empowerment, increasing persistence, supporting cooperation, enhancing students' interest and motivation, developing inquiry skills, presenting the repetition and making the course entertaining. Considering the success of our country in the field of science, it is necessary to increase the use of digital stories in order to develop these skills and to conduct further research on the subject. The experience of teacher candidates in the learning process and their applications in technology integration affect their future applications with a great deal (Bhattacherjee and Premkumar, 2004). Therefore, in the process of teacher education, it is necessary to focus on the use of digital stories in the learning and teaching process in order to enable the teacher candidates to go beyond the basic skills of the teacher and learn the learning processes in which the students are actively involved in the process and integrate the ICT. It is thought that the determination of the effects of digital story use on students' achievements and highlevel thinking skills will contribute to the literature. 


\section{Giriş}

Eğitim ortamlarına bakıldığında geçmişten günümüze kadar meydana gelen teknolojik dönüşümler sayesinde, öğrenme ve öğretme süreçlerindeki iletişim ve işbirliği ile desteklenen formal ve informal ortamların kullanımı son yıllarda oldukça artış göstermiştir. Bu durum araştırmacılar ve uygulayıcıların bir yandan teknolojiyi yaşamlarının merkezine yerleştirmiş olan öğrencilerin gereksinimleri, beklentileri ve öğrenme stillerine uygun öğrenme süreçleri tasarlamaya yöneltirken, öte yandan onları 21. yy. becerileri ile yetiştirebilme ve öğrenmelerini daha etkili hale getirebilmek için teknolojinin eğitime kaynaştıııldığı farklı arayışlara yöneltmeye başlamıştır (Barnes, Marateo ve Ferris, 2007; Chu, Tse ve Chow, 2011; Hsieh, Jang, Hwang ve Chen, 2011; Prensky, 2001). Barnes vd. (2007) göre bu dönemde öğrenenler diğer nesillere göre daha farklı düşünme ve öğrenme yapılarına sahip olduğundan onların anlamlı öğrenme deneyimleri yaşayabilmeleri için öz-yönlendirmeli öğrenme becerilerine, etkileşimli öğrenme ortamlarına ve farklı kaynaklardan alınan geribildirimlerine gereksinimleri bulunmaktadır. Yeni ortamlara ve yöntemlere gereksinim duyulan bu noktada, dijital hikayeler; çoklu ortam uygulamalarının ve yazılımlarının kullanıldığı, öğrencilere yeni öğretim yöntemleri sunan, öğrenenlerin öğrenme durumlarının içine dahil olmalarını sağlayan uygulamalar olarak karşımıza çıkmaktadır (Hung, Hwang ve Huang, 2012; Lowenthal, 2009; Lowenthal ve Dunlap, 2010). Bu anlamda dijital hikayelerin sunduğu imkanlar dijital hikayelerin eğitim alanında kullanılmasını artırmış, dijital hikaye birçok araştırma konusunun başlığı olmuştur. Alanyazına bakıldığında ise dijital hikayeler için birbirinden farklı birçok tanımın mevcut olduğu gözükmektedir. Bunlar; genel olarak dijital hikâye anlatımı, interaktif dijital bir ortamda, ses, resim, grafik, hareketli grafik, görüntü, müzik ve metne dayalı anlatımın sunulması süreci olarak tanımlanmaktadır (Meadows, 2003). Morgan'a (2014) göre; dijital hikâye anlatımları, öğrencilerin içinde bulunduğumuz çağa uygun olarak becerilerini geliştirmek, onları teşvik etmek ve öğrenmeye karşı güdülenmelerini arttırmak için kullanılabilecek yeni bir yöntemdir. Robin'e (2006) göre, dijital hikayeler; öğretmenler için etkili bir öğretim aracı, öğrenciler için ise etkili bir öğrenme aracıdır. Alanyazında dijital hikâye anlatımı ile ilgili birçok tanım bulunmasına rağmen aslında bu tanımların genel olarak resim, ses ve video gibi çoklu ortam öğelerinin öyküleme sanatıyla birleştirilmesi olarak ifade edildiği ve dijital hikayelerin genel olarak bu temalar kullanılarak tanımlandığı görülmüştür.

Bir eğitim teknolojisi aracı olan dijital hikayeler, sınıfa kazandırdığı kazanımlardan dolayı hem öğretmenler hem de araştırmacılar tarafından çok fazla ilgi görmekte ve hemen hemen her alanda kullanılmaktadır (Ohler, 2006; Weis, Benmayor, O'Leary ve Eynon, 2002). Robin'e (2008) göre öğrenme ortamları dijital hikayeler sayesinde; kullanışlı, güç, zaman ve maliyet açısından elverişli, yeninden kullanıma uygun, öğrenme bağlamını zenginleştiren ve öğrencilere pedagojik açıdan öğrenme deneyimleri kazandıran ortamlara dönüşmektedir. Malita ve Martin (2010) de araştırmalarında dijital hikayelerin bilgi ve değer paylaşımı ile birlikte önceki bilgi ve deneyimlerle bağlantı kurmada ve zihinlerin gelişimini sağlamada oldukça etkili olduğunu ortaya koymuşlardır. Alanyazındaki bazı araştırmalar ise dijital hikayelerin bilişsel etkilerinin yanı sıra öğrencilerde özgüven ve güdülenmeyi arttırmada oldukça etkili olduğunu ortaya koymaktadır (Hung vd., 2012; Kajder, 2004; Yang ve Wu, 2012).

Dijital hikayeler yalnızca geliştirme aşamasında değil, planlamadan kullanım aşamasına kadar pek çok aşamada öğrencilerin öğrenmesini desteklemektedir. Örneğin, hazırlanacak olan dijital hikâyelerin hangi mesajı içereceğine, bu mesajı iletebilmek için hangi içeriklerin kullanılacağına, bu içeriğin etkili biçimde nasıl ve hangi formatta sunulacağına, hangi görsellerin, seslerin ve müziklerin kullanılacağına karar verme; öğrencilerin bilgiyi araştırmasını, sorgulamasını, çözümlemesini, karar vermesini ve yaratıcılık ile birlikte eleştirel düşünme becerilerini kullanarak sentezlenmesini gerektirmektedir (Ohler, 2008; Sadik, 2008; Ware, 2006). Yaşanılan bu süreçler, dijital hikayelerin planlanması aşamasında kurulan iletişim ve işbirliği ile öğrencilerin karar verme, problem çözme ve eleştirel düşünme ve sorgulama gibi üst düzey düşünme becerilerinin geliştiğini göstermektedir (Chung, 2007; Kajder, 2004; Lowenthal ve Dunlap 2010; Robin, 2008; Sadik, 2008; Yang ve Wu, 2012; Ware, 2006). Örneğin, Burmark'a (2004) göre dijital hikayeler öğrencilerin bilgi toplamalarına yardımcı olan, onların yeni fikirler geliştirmelerine katkı sağlayan, bilgilerini düzenlemelerine yarayan ve onların içerik bilgilerinin gelişmesini sağlayan yöntemler arasında yer almaktadır (Akt. Robin, 2008). Yang ve Wu (2012) da öğrencilerin kendi dijital hikayelerini oluşturma sürecinde; yansıtıcı becerilerini ve eleştirel bakışları ile birlikte karar verme becerilerini de geliştirdiklerini belirtmişlerdir.

Öğrenme sürecinde öğrencilerde gelişmesi istenen özelliklerden bir diğeri de sorgulama becerisidir. Ediger'e (2001) göre öğrenciler sahip oldukları sorgulama becerileri ile sorular sormayı, araştırmalar planlamayı ve yürütmeyi, basit araçları kullanarak veriler elde etmeyi ve akla yatkın sonuçları üretmeyi gerçekleştirebilmektedirler. Benzer biçimde McGinn ve Roth'a (1999) göre de kazanılan sorgulama becerileri ile öğrenciler geleneksel yaklaşımlardan uzaklaşarak bilimsel bilgiyi yapılandırabilme ve değerlendirebilme sürecine dahil olabilmektedirler. Dijital hikayelerin gerek planlama gerekse geliştirme sürecinde sunduğu olanaklar ve öğrenciler üzerindeki etkisi göz önünde 
bulundurulduğunda öğretim ortamında dijital hikayelerin kullanımının öğrencilerin sorgulama becerileri üzerine de etkisinin olduğu düşünülmektedir. Ancak alanyazındaki araştırmalar incelendiğinde doğrudan dijital hikayelerin öğrencilerin sorgulama becerileri üzerindeki etkisini ortaya koyan bir araştırmaya rastlanmamıştır. Bu nedenle dijital hikayelerin öğrencilerin sorgulama beceriler üzerindeki etkisinin araştırılmasına gereksinim olduğu düşünülmektedir.

Öte yandan dijital hikâye geliştirme süreci öğrencilerin teknoloji kullanımını gerektirmekte, teknolojilerin kullanılarak uygulama yapma becerisi sunması ise teknoloji yeterliği kazandırmaktadır (Robin, 2008; Ware, 2006). Niemi vd., (2014) göre dijital hikayeler öğrencilerin bilgi ve becerileri, kurdukları işbirlikleri ve bağlantılar ile teknoloji yeterlikleri üzerinde oldukça büyük etkiye sahiptir. Öğrencilerin dijital hikâyelerini uygun formatta sunabilmeleri için hangi teknolojiyi kullanacaklarına karar vermeleri, bu teknolojinin kullanımı hakkında teknik becerilerini geliştirmeleri ve uygulamaya dökmeleri gerekmektedir (Sadik, 2008). Bu da onların sahip oldukları sayısal yetkinlikle bağlantılıdır. Sayısal yetkinlik kişilerin yaşam becerilerini geliştirmek ve bilgi toplumu içindeki kapasitelerini güçlendirmek amacıyla sayısal teknolojileri etkili ve verimli kullanma yeteneğidir (Makinen, 2006). Bu etkili ve verimli kullanma yalnızca teknoloji kullanım becerisi değil aynı zamanda bilgiyi anlama, değerlendirme ve bilgiyi üretme becerileri ile sayısal okuryazarlığı ve sayısal katılımcılığı da içermektedir (Akkoyunlu ve Soylu, 2010). Dijk'e (2003) göre bireylerin sayısal yetkinlik kazanmaları onların farkındalıklarının, güdülenmelerinin, teknik erişimlerinin ve teknolojik yetkinliklerinin artması ile olanaklıdır. Dijital hikâye geliştirme sürecinin bu noktada öğrencilerin sayısal yetkinlikleri üzerinde etkili olacağı düşünülmektedir.

Dijital hikayeleri geliştirirken kullanılan pek çok teknoloji arasında Web 2.0 teknolojilerinin öğrencilere büyük kolaylıklar sağladığı bilinmektedir. Web 2.0 teknolojileri sahip olduğu; çevrimiçi içerik düzenleme, bağlantı kurma, dosya yükleme, erişim, iletişim, paylaşım, tartışma, yansıtma, sunum, düzenleme, esneklik, kullanışlı, bilgi yapılandırması, işbirliği gibi özellikler sayesinde öğrencilere hikayelerini düzenleme, biçimlendirme ve aktarmada büyük özgürlük alanı sunmaktadır (Kocaman-Karoğlu, 2015; Malita ve Martin, 2010; Nelson, Christopher ve Mims, 2009; Smeda, Dakich ve Sharda, 2012; Thompson, 2007). Kajder'e (2004) göre öğrenciler Web 2.0 teknolojilerinin kullanıldığı hikâye geliştirme süreçlerinde; formal ve informal öğrenme ortamlarında çalışarak, tasarımcı, dinleyici, yorumlayıcı, okuyucu, yazııı, iletişimci, sanatçı, düşünen gibi roller üstlenirler ve kendilerini geliştirirler. Standley'e (2003) göre ise bu teknolojileri kullanarak geliştirilen hikayelerin herkes tarafından görünür olması ve tartışılması öğrencilerin ilgilerini ve daha iyi ürün ortaya koyabilmek için güdülenmelerini arttırmaktadır (Akt; Sadik, 2008). Bu nedenle dijital hikâye geliştirme süreçlerinin Web 2.0 teknolojilerle desteklenmesinin hem öğrenciye hem de öğrenme sürecine katkı sağlayacağı kaçınılmaz bir gerçek olarak gözükmektedir.

Dijital hikâye geliştirme sürecinin sahip olduğu bütün bu özellikler dikkate alındığında, dijital hikâye yaklaşımının öğrencinin kendilerini ifade etmelerine, araştırma, problem çözme, sorgulama gibi becerilerine; etkili teknoloji kullanımı yeterliğine ve düşüncelerini, yaratıcıııklarını, hayal güçlerini anlamlı bir biçimde ortaya koyabilmelerine katkı sağlayabildiği görülmektedir. Dolayısıyla, bu yaklaşım çağın kaliteli ve nitelikli birey arayışına yanıt olabilecek eğitim ortamını sağlaması bağlamında önem taşımaktadır.

Alanyazında konu ile ilgili araştırmalar incelendiğinde öğretmen adaylarının dijital hikayeleri öğrenme ve öğretme sürecinde Türkçe, Matematik, Tarih, Dil Öğretimi gibi pek çok alanda kullandığı (Dupain ve Maguire, 2005; Karataş, Bozkurt ve Hava, 2016; Özpınar, 2017; Robin, 2008; Sadik, 2008; Uslupehlivan, Erden ve Cebesoy, 2017), ayrıca son dönemlerde Fen eğitimi alanında da etkili bir biçimde kullanılmaya başlandığı görülmektedir (Hung vd., 2012; Kahraman, 2013; Sancar-Tokmak, Sürmeli ve Özgelen, 2014; Ulum ve Ercan-Yaman, 2018). Çünkü günümüzde hazır bilgiyi alarak ezberleyen bireyler yerine üst düzey düşünme becerilerine sahip bireylere gereksinim duyulmaya başlamış, bu gereksinim göz önünde bulundurulduğunda ise pek çok alanda olduğu gibi Fen bilimleri alanında da bu becerilere sahip öğrencilerin yetiştirilmesi ihtiyacı oluşmaya başlamıştır. Ancak ne yazık ki ülkemizde Fen bilimleri alanında öğrencilerin başarıları oldukça düşük olduğu görülmektedir. Öğrenci Seçme ve Yerleştirme Merkezi'nin (ÖSYM) yayınladığı 2018 Yüksek Öğretim Kurumları (YKS) Değerlendirme Raporunda sınava giren öğrencilerin Fen Bilimleri alanında 2.8 ortalamasının olması (ÖSYM, 2018) bu alanda başarının ne kadar düşük olduğunu net bir biçimde ortaya koymaktadır. Öte yandan uluslararası düzeyde yapılan ülkelerin Fen ve Okuma gibi temel alanlardaki başarılarının ortaya koyulduğu PISA ve TIMMS gibi sınavlarda ülkemizin ortalamanın altında kalması öğrencilerin bu becerilerinin geliştirilmesine duyulan gereksinimin bir başka göstergesidir. Ülkemizde Fen bilimleri eğitimi alanında dersin adı, içeriği, öğretim yöntemleri ve dersin işleniş biçimi gibi pek çok alanda birtakım düzenlemeler yapılmasına rağmen teknolojiyi etkili kullanabilen, eleştirel bakabilen, problem çözebilen ve sorgulayabilen bireylerin yetişebilmesi için öncelikle öğretmenlerin bu becerilere sahip bir biçimde yetişmesi ve desteklenmesine yönelik çalışmaların artırılması ve var olan çalışmaların geliştirilmesi gerekmektedir. Aydoğmuş, Sarıkoç ve Berber’e (2010) göre 
öğrencilerin fen bilgisi derslerindeki başarılarını arttırmak için öğrencilerin derse olan bakış açılarını değiştirmek, öğrencilerin derse aktif katılımını sağlamak, süreçte onlara uygulama ve gözlem olanağı sunmak, yeni ve etkili yöntemleri dersin öğretiminde uygulamak gerekmektedir.

Bu anlamda öğrencilerin gelişimi kadar öğretmen adaylarının da öğretmen eğitim sürecinde kazandırımak istenen bilgi ve becerilere uygun biçimde yetişmesi için düzenlemelere ve teknoloji ile desteklenmiş uygulamalara gereksinim duyduğunu göstermektedir (Sancar-Tokmak ve diğerleri, 2014). Başka bir değişle, öğrencilerin fen ve teknoloji alanında beklentilere uygun bir biçimde yetişebilmesi için öğretmen adaylarının da zengin ders içeriği hazırlamak ve öğrencilere sınıfta rehber olabilmek için yeni teknolojilere yönelik beceriler ve yetkinlikler elde etmesi ve bu araçları kullanarak nasıl öğretim gerçekleştirebileceğini bilmesi, bu araçları etkili kullanabilmesi, sınıf yönetimi uygulamaları için bu teknolojileri nasıl bir araya getirebileceğini bilmesi gerekmektedir. Öğretmen adaylarının öğrenim sürecindeki deneyimleri ve teknoloji entegrasyonu konusundaki uygulamaları onların gelecek uygulamalarını fazlası ile etkilemektedir (Bhattacherjee ve Premkumar, 2004). Bu nedenle öğretmen eğitimi sürecinde öğretmen adaylarına temel becerileri öğretmenin ötesine geçerek yenilikçi, öğrencilerin aktif olarak sürecin içinde yer aldığı ve BiT’i entegre ettiği öğrenme süreçlerini yaşaması gerekmektedir (Haugerund, 2011). Öğretmen adaylarında bu dijital yeterlikleri geliştirmelerinin yolu ise dijital hikâyelerdir (Heo, 2009, 2011). Dreon, Kerper ve Landis (2011) ve Heo (2011) öğretmen adaylarının dijital hikayelerin eğitimde kullanımı konusunda süreç hakkında derin anlamlar kazanmaları gerektiğini ve bu hikayeleri etkili bir biçimde kullanabilmek adına nelerin yapılabileceğini öğrenmeleri gerektiğini vurgulamıştır. Bu da öğretmen adaylarının dijital hikâye geliştirme süreci ile birlikte teknoloji, pedagoji ve alan bilgisinin birleştirilerek ürünler ortaya koyabilmeyi öğrenmesi gerektiğini ve bu konuda desteklenmesi gerektiğini göstermektedir. Judge, Puckett ve Cabuk (2004) öğretmenlerin özgüvene ve beceriye yeterince sahip olmaları durumunda öğretim programlarına bu teknolojiyi dâhil edebileceklerini, bunun için de eğitime, zamana ve öz-yönelimli keşfetme ve öğrenme için zamana gereksinimleri olduğunu belirtmiştir.

Buradan hareketle, araştırmada Web 2.0 teknolojileri ile desteklenmiş dijital hikâye geliştirme ortamını laboratuvar uygulama dersinde kullanan biyoloji öğretmeni adaylarının süreç sonundaki başarılarını, sayısal yetkinlik durumlarını ve sorgulayıcı öğrenme durumlarını incelemek amaçlanmıştır. Bu genel amaç çerçevesinde aşağıdaki araştırma sorularına yanıt aranmıştır. Bu sorular;

1. Laboratuvar uygulama dersinde dijital hikâye geliştirme ortamını kullanan adaylar ile kullanmayan adayların akademik başarılarını arasında anlamlı bir fark var mıdır?

2. Laboratuvar uygulama dersinde dijital hikâye geliştirme ortamını kullanan adaylar ile kullanmayan adayların sayısal yetkinlikleri arasında anlamlı bir fark var mıdır?

3. Laboratuvar uygulama dersinde dijital hikâye geliştirme ortamını kullanan adaylar ile kullanmayan adayların sorgulama beceri durumları arasında anlamlı bir fark var mıdır?

4. Laboratuvar uygulama dersinde dijital hikâye geliştirme ortamını kullanan adayların ortama yönelik görüşleri (olumlu ve olumsuz görüşleri, algıladıkları farklı yönleri, ortamın kullanılabilirliğine yönelik görüşleri) nelerdir?

\section{Yöntem}

\section{Araştırmanın Modeli}

Bu çalışmada karma yöntem kullanıımıştır. Karma yöntem bir araştırma programı kapsamında yapılan çalışmalar içerisinde, nicel ve nitel verilerin toplanmasını ve çözümlenmesini kapsamaktadır (Creswell ve Plano-Clark, 2007). Araştırmada karma yöntem desenlerinden iç içe desen kullanılmıştır. İç içe karma desenlerde deneysel çalışmaları desteklemek için nitel araştırma yöntemlerinden yararlanılmaktadır. Bu araştırmanın nicel kısmında ön test - son test kontrol gruplu yarı deneysel desen kullanılmış olup, elde edilen verileri desteklemek için ise yapılandırılmış görüşmeler yapılmıştır.

\section{Çalışma Grubu}

Araştırmada seçilen çalışma grubunu; 2015-2016 eğitim-öğretim yılında, Necmettin Erbakan Üniversitesi, Ahmet Keleşoğlu Eğitim Fakültesi, Matematik ve Fen Bilimleri Eğitimi Bölümü, Biyoloji Eğitimi Anabilim Dalı 2. Sınıf'ında eğitim ve öğrenimine devam eden (deney grubu- $\mathrm{N}=21$ ve kontrol grubu- $\mathrm{N}=18$ ) toplam 39 kişilik biyoloji öğretmeni adayı 
oluşturmaktadır. Grupların deney ve kontrol gruplarına atanması seçkisiz atama yöntemi ile gerçekleşmiştir. Çalışma grubunun cinsiyet değişkenine ait dağılımı Tablo 1'de verilmiştir.

Tablo 1. Çalışma Grubu Cinsiyet Dağılımı

\begin{tabular}{|c|c|c|c|c|c|c|}
\hline \multirow[t]{2}{*}{ Cinsiyet } & \multicolumn{2}{|c|}{ Deney Grubu } & \multicolumn{2}{|c|}{ Kontrol Grubu } & \multicolumn{2}{|c|}{ Deney ve kontrol grubu } \\
\hline & f & $\%$ & $\mathbf{F}$ & $\%$ & f & $\%$ \\
\hline Erkek & 6 & $\begin{array}{l}28, \\
5\end{array}$ & 1 & 5,5 & 7 & 17,9 \\
\hline Kadın & 15 & $\begin{array}{l}71, \\
5\end{array}$ & 17 & 94,5 & 32 & 82,1 \\
\hline Toplam & 21 & 100 & 18 & 100 & 39 & 100 \\
\hline
\end{tabular}

Tablo 1'de deney ve kontrol grubunda yer alan öğrencilerin cinsiyet değişkenine göre dağılımları arasındaki benzerlik dikkati çekmektedir. Ayrıca, her iki grubun aynı bölüm öğrencileri olması, üniversiteye giriş puanlarının aynı olması ve Tablo 2.'de gösterilen "Akademik Başarı Testi Ön Test Karşılaştırma Sonuçlarının" benzer çıkması [t(37)=.023, $p>0.05$ ] nedeni ile iki grubun denk olduğu söylenebilir. Deney grubunda $(N=21) 6$ erkek $(\% 28,5), 15$ kadın $(\% 71,5)$, kontrol grubunda $(\mathrm{N}=18) 1$ erkek $(\% 5,5), 17$ kadın $(\% 94,5)$ ve toplamda 7 erkek $(\% 17,9), 32$ kadın $(\% 82,1)$ çalışma grubunu oluşturmaktadır.

Deney ve kontrol grubuna uygulama öncesi akademik başarı testi uygulanmıştır. Tablo 2'de deney ve kontrol gruplarının akademik başarı ortalamaları, standart sapmaları ve bağımsız gruplar $t$ test sonuçları yer almaktadır.

Tablo2. Gruplar Arası Akademik Başarı Testi Ön Test Karşılaştırma Sonuçları

\begin{tabular}{|c|c|c|c|c|c|c|c|}
\hline Gruplar & & $\mathbf{N}$ & $\overline{\mathbf{x}}$ & Ss & Sd & $\mathbf{t}$ & $p$ \\
\hline \multirow[t]{2}{*}{$\begin{array}{l}\text { Ön } \\
\text { test }\end{array}$} & $\begin{array}{l}\text { Deney } \\
\text { grubu }\end{array}$ & 21 & 49,19 & 10,61 & 37 & ,023 & $.662^{*}$ \\
\hline & $\begin{array}{l}\text { Kontrol } \\
\text { grubu }\end{array}$ & 18 & 47,72 & 10,08 & & & \\
\hline
\end{tabular}

$* p<0.05$

Çalışma grubu öğrencilerinin benzer yerleştirme puanları ile aynı bölüme yerleşmiş olmaları ve seçkisiz atama yöntemi ile deney ve kontrol gruplarının atanması ile ayrıca, Tablo 2 incelendiğinde, deney ve kontrol gruplarının araştırma öncesi başarı ortalamaları arasında istatistiksel olarak anlamlı bir farklılık bulunmadığı görülmektedir $[\mathrm{t}(37)=.023, \mathrm{p}>0.05]$. Belirtilen tüm bu durumlar deney ve kontrol gruplarının denk olarak kabul edilmesinde bir sakınca olmadığı anlamına gelmektedir.

\section{Veri Toplama Araçları}

Bu çalışmada veri toplama aracı olarak öncelikle araştırmacılar tarafından geliştirilen "Kişisel Bilgi Formu" ve "Akademik Başarı Testi", Aldan-Karademir ve Saraçoğlu (2013) tarafından geliştirilen "Sorgulama Becerileri Ölçeği", Akkoyunlu, Yılmaz Soylu ve Çağlar (2010) tarafından geliştirilen "Sayısal Yetkinlik Ölçeği” ve araştırmacılar tarafından geliştirilen "Dijital Hikâye Geliştirme Ortamının Kullanımına Yönelik Yapılandırılmış Görüşme Formu” kullanılmıştır.

Kişisel Bilgi Formu, katılımcıların demografik özelliklerini belirlemeye yönelik sorulardan oluşmaktadır. Akademik başarı testi ise alan uzmanları tarafından geliştirilen ve 25 çoktan seçmeli test sorusundan oluşan bir testtir. Akademik başarı testindeki sorular dersin öğretim elemanı tarafından hazırlanan belirtke tablosundaki her bir kazanım için en az 2 ya da 3 soru olacak biçimde oluşturulmuştur. Sorular oluşturulurken; bilgi soruları, kavrama soruları ve kavramsal sorular (analiz- sentez soruları) olarak Bloom'un taksonomisindeki basamaklara göre hazırlanmasına dikkat edilmiştir. Oluşturulan akademik başarı testi uygulama öncesi 3 alanın uzmanı tarafından incelenmiş ve bu uzmanların görüşlerine göre tekrar düzenlenerek son hali verilmiştir. Başarı testi çalışma grubu öğrencilerine uygulandıktan sonra doğru cevaplar 1, yanlış cevaplar 0 biçiminde düzenlenerek teste ait istatistiksel analizler yapılmıştır. Madde analiz çalışmasında, Kuder-Richardson-20 (KR-20) tekniği ile testin güvenirliği belirlenmiştir. Yapılan KR-20 testinin değeri 
.810 olarak belirlenmiştir. Testin ortalama madde güçlük değeri 0.513 olarak bulunmuştur. Bu sonuçlar araştırmada kullanılan akademik başarı testinin zorluk düzeyinin normal zorlukta olduğunu göstermektedir.

Araştırmada kullanılan ölçeklerden biri "Sorgulama Becerileri Ölçeği"dir. "Sorgulama Becerileri Ölçeği" AldanKarademir ve Saraçoğlu (2013) tarafından geliştirilen 5'li likert tipinde 3 faktörlü yapıda 14 maddeden oluşan bir ölçektir. Her bir faktör, kuramsal çerçeve doğrultusunda "Bilgi Edinme", "Bilgiyi Kontrol Etme" ve "Özgüven" olarak adlandırılmıştır. Güvenirlik katsayıları "Bilgi Edinme" için .76; "Bilgiyi Kontrol Etme" için .66 ve "Özgüven" için .82 iken, ölçeğin toplamı için .82 'dir.

Araştırmada kullanılan ölçeklerden bir diğeri "Sayısal Yetkinlik Ölçeği"dir. Bu ölçek Akkoyunlu, Yılmaz Soylu ve Çağlar (2010) tarafından geliştirilmiş olup 7'li likert tipinde dört faktörlü yapıda 45 maddeden oluşmaktadır. Her bir faktör; "Farkındalık", "Motivasyon", "Teknik Erişim" ve "Yetkinlik" olarak adlandırıımıştır. Güvenirlik katsayıları ölçeğin tamamında .86, "Farkındalık" için .94, "Motivasyon" için .84, üçüncü alt boyutunda "Teknik Erişim" için .78 ve "Yetkinlik" için .81 iken, ölçeğin tamamı için .86'dır. 45 maddeden oluşan bu ölçekte genelde alınabilecek en yüksek puan 315 , en düşük puan ise 45 olabilmektedir. Bu durumda yanıt verenlerin elde ettikleri puan 45-135 puan aralığında ise sayısal yetkinlik düzeyi düşük, 136-225 puan aralığı sayısal yetkinlik düzeyi orta ve 226-315 puan aralığı ise sayısal yetkinlik düzeyi yüksek olarak kabul edilmiştir.

Araştırmanın son kısmında nitel veriler toplamak amacı ile geliştirilen "Dijital Hikâye Geliştirme Ortamının Kullanımına Yönelik Yapılandırılmış Görüşme Formu" kullanılmıştır. Bu form öğrencilerin dijital hikâye geliştirme ortamlarını kullanım durumlarını belirlemek amacı ile araştırmacılar tarafından geliştirilen 8 açık uçlu sorudan oluşmaktadır. Sorular 3 alan uzmanı ve 1 dil uzmanı tarafından incelenerek yapılan düzenlemelerle, açık uçlu 4 soru biçiminde son haline getirilmiştir.

\section{Araştırmanın Uygulanması}

Çalışmaya başlamadan önce grupların deney ve kontrol gruplarına atanması seçkisiz atama yöntemi ile gerçekleştirilmiştir. Öğrencilere uygulama sürecine başlamadan önce çalışma hakkında detaylı bilgi verilerek çalışma için gerekli onayları alınmıştır. Çalışma süresi 14 haftalık bir süreci kapsamaktadır. Çalışma ve deney grubu öğrencileri 3-4 kişilik grup kurarak aşağıda belirtilen işbirliklli teknolojileri kullanarak 14 haftalık uygulama sürecinde kendilerine verilen görevleri ekip çalışması ile yerine getirmişlerdir. Çalışmada ilk olarak deney ve kontrol grubu öğrencilerine "Kişisel Bilgi Formu", "Akademik Başarı Testi", "Sorgulama Becerileri Ölçeği”, "Sayısal Yetkinlik Ölçeği” uygulanmıştır. Daha sonra 10 haftalık süreçte deney grubu öğrencileri Web 2.0 teknolojilerinin desteği ile tasarlanmış bir laboratuvar ortamında, kontrol grubu öğrencileri ise geleneksel yöntemlerle "Laboratuvar Uygulamaları" dersi süreci yönetilmiştir. Araştırmada kullanılan web teknolojileri; Google+ Circle (Plus), Google+ Documents, Google+ Blogger, Google Hangouts, Google+ Drive, Google Calendar ve Google Chat (Talk)'dir. Araştırmada Google teknolojilerinin seçilmesinin avantajı; uygulamaların tümünün gmail platformundan kullanıcı adı ve şifre alındıktan sonra diğer tüm teknolojilerin (Google plus, document, chat, mail, drive, hangout vb.) birbirleri arasında erişim sağlanarak tek kullanıcı adı ve şifre ile kullanılabilmesidir. Uygulama ortamında işbilrilkli teknolojiler ile dijital hikâye ortamlarının geliştirilmesi ve kullanılmasının en önemli avantajı, klasik hikâyelerin dezavantajlı olan bir çok yönünü ortadan kaldırması ve çoklu bir ortamda ve çoklu bir bakış açısıyla tekrar tekrar ulaşılabilir olmasıdır. Iş̧birlikli teknolojiler ile geliştirilen dijital hikayelerin bir çok kişinin berabere kullanabildiği geliştirilebilir bir ortam olması avantajlı yönüdür. Ayrıca teknolojinin yaratıcılıkla birleşmesiyle oluşan dijital hikâye anlatımları sayesinde öğrencilerin dünyayı, değişik şekillerde görüp, duyup ve algılaması başka bir avantajıdır. Buradan hareketle birçok duyuya ve beceriye hitap eden dijital hikâye anlatımları, öğretim açısından uygun birer materyal olabilirler (Robin, 2008; Hess,2014; Kurudayıoğlu ve Bal, 2014; Matthews,2014; Toki ve Pange,2014). Ayrıca, diğer sosyal ağlardaki eğitim dışındaki paylaşımlardan uzak olarak, sadece paylaşılan içerik dışındaki, ders dışı video, resim, metin gibi dosyaların olmamasıdır. Dolayısıyla uygulama öğrencilerinin ders dışı etkinlik ve paylaşımlarla dikkatleri dağılmayacağından dolayı bilişsel yük en aza indirilebilmektedir. Uygulama sürecinin ardından tekrar "Akademik Başarı Testi", "Sorgulama Becerileri Ölçeği" ve "Sayısal Yetkinlik Ölçeği" uygulanmıştır. Son olarak, deney grubu öğrencileri ile dijital hikâye geliştirme sürecindeki deneyimlerini ayrıntılandırabilmek için "Dijital Hikaye Geliştirme Ortamının Kullanımına Yönelik Yapılandırılmış Görüşme Form" u kullanılarak görüşmeler yapılmıştır. Çalışmanın uygulama sürece Tablo 5'de verilmektedir. Uygulama süresince deney grubu öğrencilerin tasarladıkları içerikler, deneylerin uygulama sürecinde çekmiş ve grup bloglarından paylaşmış oldukları videolar, Google Hangout'da yapmış oldukları grup toplantılarına yönelik görüntüler ve Google Document'de geliştirip Google Drive'da paylaşmış oldukları içeriklere yönelik görüntüler ayrıntılı olarak verilmektedir (EK1). 
Tablo 3. Uygulama Süreci

\begin{tabular}{|c|c|c|}
\hline \multirow[t]{2}{*}{ Hafta } & \multicolumn{2}{|l|}{ Uygulama } \\
\hline & Deney Grubu & Kontrol Grubu \\
\hline 1 & Çalışma hakkında bilgi verilmesi & Çalışma hakkında bilgi verilmesi \\
\hline 2 & $\begin{array}{l}\text { Ön test uygulanması ("Akademik } \\
\text { Başarı Testi", "Sorgulama Becerileri } \\
\text { Ölçeği", "Sayısal Yetkinlik ölçeği" ve } \\
\text { "Kişisel Bilgi Formu") }\end{array}$ & $\begin{array}{l}\text { Ön test uygulanması (“Akademik Başarı } \\
\text { Testi", "Sorgulama Becerileri Ölçeği", } \\
\text { "Sayısal Yetkinlik ölçeği" ve "Kişisel Bilgi } \\
\text { Formu") }\end{array}$ \\
\hline 3 & $\begin{array}{l}\text { Web } 2.0 \text { teknolojilerinin tanıtılması, } \\
\text { öğrencilerin heterojen gruplara } \\
\text { ayrılması ve projelerin belirlenmesi }\end{array}$ & $\begin{array}{l}\text { Öğrencilerin heterojen gruplara ayrılması ve } \\
\text { projelerin belirlenmesi }\end{array}$ \\
\hline 4 & - Projeye başlanılması, & Ders vöntemi olarak dersin islenmesi \\
\hline 5 & $\begin{array}{l}\text { - Haftalık Google Hangout toplantıları, } \\
\text { bir sonraki hedefin belirlenmesi, Deney }\end{array}$ & 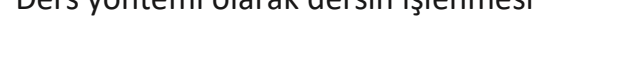 \\
\hline 6 & yapılması sürecinde ya da & \\
\hline 7 & $\begin{array}{l}\text { laboratuvarda yaşanan olumlu ve } \\
\text { olumsuz tecrübelerin } \quad \text { Google }\end{array}$ & \\
\hline 8 & Documents kullanılarak belirlenmesi, & \\
\hline 9 & $\begin{array}{l}\text { - Gerçekleştirilen projenin adımlarının } \\
\text { oluşturulan bir blogta paylaşıması ve } \\
\text { grupların birbirlerinin projelerini } \\
\text { değerlendirmesi }\end{array}$ & \\
\hline 10 & $\begin{array}{l}\text { Son test uygulanması ("Akademik } \\
\text { Başarı Testi", "Sorgulama Becerileri } \\
\text { Ölçeği", "Sayısal Yetkinlik ölçeği" ve } \\
\text { Dijital Hikâye Geliştirme Ortamının } \\
\text { Kullanımına Yönelik Yapılandırılmış } \\
\text { Form) }\end{array}$ & $\begin{array}{l}\text { Son test uygulanması ("Akademik Başarı } \\
\text { Testi", "Sorgulama Becerileri Ölçeği", } \\
\text { "Sayısal Yetkinlik ölçeği") }\end{array}$ \\
\hline
\end{tabular}

\section{Verilerin Çözümlenmesi}

Araştırma kapsamında elde edilen veriler SPSS programı kullanılarak çözümlenmiş ve $p=0.05$ anlamlılık düzeyinde test edilmiştir. Araştırma kapsamında elde edilen veriler parametrik test varsayımlarını karşıladığından $(\mathrm{N}=39)$ ve veriler normal dağııım gösterdiklerinden dolayı (SPSS analizinde bu testi yapabilmek için normallik dağılım testinin yapılması gerekmektedir. Paremetrik tesleri kullanmak için yapılan testler şunlardır; Kolmogorov Smirnov ve Shapiro Wilk testleri. Paremetrik tesleri kullanmak için hem kolmogorov Smirnov testi hem de Shapiro Wilk testlerinde anlamlılık değerinin yani $p$ değerinin $p<0,05$ ve üzerinde olması gerekmektedir. Kolmogorov Smirnov testinde hedef kitle 30 ve üstündeki örnekleme uygulanırken 30 ve altındaki örneklemde normallik dağııımı için Shapiro Wilk testi uygulanmaktadır. Araştırmanın çalışma grubu 30'un üzerinde olduğu için Kolmogorov Smirnov testi kullandık ve $p$ değeri 0,005 olarak belirlenmiştir. Ayrıca, bir diğer husus olan Kurtosis veya Basıklık değeri de önemlidir. Normal dağılım ölçütü veya normal dağıım testi olarak bir çok çalışma K-S testi veya Shapiro Wilk testini uygularken bazı çalışmalar ise Skewness ve Kurtosis yani çarpıklık ve basıklık değerini göz önüne alınmaktadır. Bu değerlerin verilerin basıklık ve çarpıklık değeri -1ile +1 arasındaysa verilerin normal dağıldığı varsayılmaktadır.), verilerin çözümlenmesinde parametrik testlerden yararlanılmıştır. Bu bağlamda, her bir alt amaç için kullanılan testler aşağıda açıklanmıştır. Katılımcılardan toplanan demografik veriler betimsel istatistik yöntemlerinden frekanslar verilerek açıklanmıştır. Çalışma grubunun veri toplama araçlarından aldıkları sonuçların farklılıklarını belirlemek için, ilişkili ve ilişkisiz örneklemler için t-testi kullanılmıştır. Araştırmanın nitel analizinde ise içerik çözümlemesi yapılmıştır. İçerik çözümlemesinde öncelikle öğrencilerin vermiş oldukları yanıtlar tek tek kodlanmış, ardından inandırııılığı ve onaylana bilirliği sağlamak için bir uzman ile birlikte çalışılarak kodlar belli temalar altında gruplandırılmıştır. Araştırmada belirlenen temalar okuyucunun anlayabileceği biçimde yorum katılmadan doğrudan alıntılar kullanılarak raporlaştırılmıştır. Alıntılar verilirken katılımcıların gizliliğini sağlayabilmek için öğrenciler K1, K2, ..., K21 biçiminde isimlendirilmiştir. 


\section{Bulgular}

Bu bölümde araştırmada elde edilen veriler doğrultusunda akademik başarı, sayısal yetkinlik durumları ve sorgulama becerilerine yönelik bulgular verilecek ve bu bulgular yorumlanacaktır. Ayrıca görüşmelerden elde edilen veriler doğrultusunda araştırmanın nitel kısmına ait bulgular da verilerek açıklaması yapılacaktır.

\section{Akademik Başarıya ilişkin Bulgular}

Laboratuvar uygulama dersinde Web 2.0 teknolojileri destekli dijital hikâye ortamını kullanan adaylar ile kullanmayan adayların akademik başarılarını arasında anlamlı bir fark olup olmadığını belirlemek amacı ile deney ve kontrol gruplarındaki öğrencilerin öntest ve son test başarı puanları karşılaştırılmıştır. Uygulama sonrasında deney grubu öğrencilerinin akademik başarı durumlarını belirlemek için yapılan ön test ve son testlerin karşılaştırmalarının sonucu Tablo 4'de verilmiştir.

Tablo 4. Deney Grubu Akademik Başarı Ön Test-Son Test Karşılaştırma Sonuçları

\begin{tabular}{llllllll}
\hline Deney & Test & $\mathbf{N}$ & $\overline{\mathbf{x}}$ & Ss & Sd & $\mathbf{t}$ & $\mathbf{p}$ \\
\cline { 2 - 7 } Grubu & Ön test & 21 & 49.19 & 10.61 & 20 & 21.23 & .000 \\
& Son test & 21 & 82.19 & 10.61 & & & \\
\hline
\end{tabular}

${ }^{*} p<0.05$

Tablo 4 incelendiğinde deney grubunda öğrencilerin başarılarında anlamlı bir artış olduğu görülmektedir $\left[t_{(20)}=21.23, p<.05\right)$. Deney grubu öğrencilerinin başarı ortalaması $\bar{x}=49.19$ iken, dijital hikâye ortamını kullanımları sonucunda başarı ortalaması $\bar{x}=82.19$ 'a yükselmiştir.

Uygulama sonucunda kontrol grubu öğrencilerinin akademik başarı durumlarını ortaya koymak için yapılan ön test ve son testlerin karşılaştırmalarının sonucu Tablo 5' de verilmiştir.

Tablo 5. Kontrol Grubu Akademik Başarı Ön Test-Son Test Karşılaştırma Sonuçları

\begin{tabular}{llllllll}
\hline $\begin{array}{l}\text { Kontrol } \\
\text { Grubu }\end{array}$ & Test & $\mathbf{N}$ & $\overline{\mathbf{x}}$ & Ss & Sd & $\mathbf{t}$ & $\mathbf{p}$ \\
\cline { 2 - 8 } & $\begin{array}{l}\text { On test } \\
\text { Son }\end{array}$ & 18 & 47.71 & 10.08 & 17 & 20.08 & .000 \\
& $\begin{array}{l}\text { Sest } \\
\text { tes }\end{array}$ & 72.72 & 10.08 & & & \\
\hline
\end{tabular}

${ }^{*} p<0.05$

Tablo 5 incelendiğinde kontrol grubunda öğrencilerin başarılarında anlamlı bir artış olduğu görülmektedir $[t(17)=20.08, p<.05)$. Kontrol grubu öğrencilerinin başarı ortalaması $\bar{x}=47,71$ iken, katıldıkları uygulama sonucunda başarı ortalaması $\bar{x}=72,72$ 'ye yükselmiştir.

Dijital hikâye geliştirme ortamını kullanan öğrenciler ile kullanmayan öğrencilerin süreç sonundaki akademik başarıları karşılaştıııldığında ortaya çıkan sonuç Tablo 6 'da verilmiştir.

Tablo 6. Gruplar Arası (Deney - Kontrol Grubu) Akademik Başarı Son Test Karşılaştırma (T - Testi) Sonuçları

\begin{tabular}{llllllll}
\hline Gruplar & & $\mathrm{N}$ & $\overline{\mathrm{x}}$ & $\mathrm{S}$ & $\mathrm{Sd}$ & $\mathrm{t}$ & $\mathrm{p}$ \\
\hline $\begin{array}{l}\text { Son } \\
\text { test }\end{array}$ & Deney grubu & 21 & 82.19 & 10.61 & 37 & .02 & .0 \\
& & & & & & & 07 \\
& Kontrol grubu & 18 & 72.72 & 10.08 & & & \\
\hline
\end{tabular}

${ }^{*} \mathrm{p}<0.05$

Tablo 6 incelendiğinde, uygulama sonrası deney ve kontrol grubuna yapılan son testlerdeki başarı puanları arasında anlamlı bir farklılık olduğu görülmektedir [t(37)=0.02, $\mathrm{p}<.05]$. Yapılan son testlerde deney grubu başarı ortalaması $\bar{x}=82.19$ iken, kontrol grubu başarı ortalaması $\bar{x}=72.72$ olarak hesaplanmıştır. Bu sonuç gerçekleştirilen uygulamanın deney grubu lehine olduğunu göstermektedir. Öte yandan, Dijital hikâye ortamının, akademik başarı üzerindeki etki büyüklüğünü belirlemek için eta kare değeri incelenmiştir. Etki büyüklüğü değerleri $\eta 2=.118$ olarak hesaplanmıştır. 
Etki büyüklüğü değeri göz önünde bulundurulduğunda, dijital hikâye geliştirme ortamının, akademik başarı üzerinde "düşük" bir etki değerine sahip olduğu söylenebilir.

\section{Sayısal Yetkinlik Durumlarına İlişkin Bulgular}

Laboratuvar uygulama dersinde Web 2.0 destekli dijital hikaye geliştirme ortamını kullanan adaylar ile kullanmayan adayların sayısal yetkinlikleri arasında anlamlı bir fark olup olmadığını belirlemeye yönelik bulgular Tablo 7'de verilmiştir.

Tablo 7. Gruplar Arası Sayısal Yetkinlik Ölçeği Son Test Karşılaştırma Sonuçları

\begin{tabular}{llllllll}
\hline Gruplar & & $\mathbf{N}$ & $\overline{\mathbf{x}}$ & $\mathbf{S}$ & $\mathbf{S d}$ & $\mathbf{t}$ & $\mathbf{p}$ \\
$\begin{array}{l}\text { Son } \\
\text { test }\end{array}$ & Deney grubu & 21 & 167.71 & 23.19 & 37 & .08 & .009 \\
& & & & & & 7 & \\
& Kontrol grubu & 18 & 147.11 & 23.00 & & & \\
\hline
\end{tabular}

$* p<0.05$

Tablo 7 incelendiğinde uygulama sonrası deney ve kontrol grubuna yapılan son testlerdeki sayısal yetkinlik puanları arasında anlamlı bir farklılık olduğu görülmektedir $\left[\mathrm{t}_{(37)}=0.08, \mathrm{p}<.05\right]$. Yapılan son testlerde ölçeğe ait toplam test puanlarının ortalaması olarak; deney grubu test ortalaması $\bar{x}=167.71$ iken, kontrol grubu test ortalaması $\bar{x}=147.11$ olarak hesaplanmıştır. Bu sonuç gerçekleştirilen uygulamanın deney grubu lehine olduğunu göstermektedir. Ayrıca dijital hikâye geliştirme ortamının, sayısal yetkinlik durumları üzerindeki etki büyüklüğünü belirlemek için eta kare değeri incelenmiştir. Etki büyüklüğü değerleri $\eta 2=.181$ olarak hesaplanmıştır. Etki büyüklüğü değeri göz önünde bulundurulduğunda, dijital hikâye geliştirme ortamının, sayısal yetkinlik durumlarının üzerinde "geniş" bir etki değerine sahip olduğu söylenebilir.

\section{Sorgulama Becerilerine ilişkin Bulgular}

Laboratuvar uygulama dersinde dijital hikâye geliştirme ortamını kullanan adaylar ile kullanmayan adayların sorgulama beceri durumları arasında anlamlı bir fark olup olmadığını belirlemeye yönelik bulgular Tablo 8'de verilmiştir.

Tablo 8. Gruplar Arası Sorgulama Becerileri Ölçeği Son Test Karşılaştırma Sonuçları

\begin{tabular}{llllllll}
\hline \multicolumn{1}{c}{ Gruplar } & & $\mathbf{N}$ & $\overline{\mathbf{x}}$ & $\mathbf{S}$ & $\mathbf{S d}$ & $\mathbf{t}$ & $\mathbf{p}$ \\
\hline $\begin{array}{l}\text { Son } \\
\text { test }\end{array}$ & Deney grubu & 21 & 43.28 & 13.46 & 37 & .117 & .003 \\
& Kontrol grubu & 18 & 33.16 & 14.70 & & & \\
\hline
\end{tabular}

$* p<0.05$

Ön testleri Tablo 2'de verilmiş e anlamlı bir farklılık bulunamamıştır. Tablo 8 incelendiğinde uygulama sonrası deney ve kontrol grubuna yapılan son testlerdeki sorgulama becerileri puanları arasında anlamlı bir farklılık olduğu görülmektedir $\left[\mathrm{t}_{(37)}=0.11, p<.05\right]$. Yapılan son testlerde deney grubu test ortalaması $\bar{x}=39,40$ iken, kontrol grubu test ortalaması $\bar{x}=30,77$ olarak hesaplanmıştır. Bu sonuç gerçekleştirilen uygulamanın deney grubu lehine olduğunu göstermektedir. Ayrıca, dijital hikâye geliştirme ortamının, sorgulama becerileri üzerindeki etki büyüklüğünü belirlemek için eta kare değeri incelenmiştir. Etki büyüklüğü değerleri $\eta 2=.095$ olarak hesaplanmıştır. Etki büyüklüğü değeri göz önünde bulundurulduğunda, dijital hikâye geliştirme ortamının, sorgulama becerileri üzerinde "orta" bir etki büyüklüğüne sahip olduğu söylenebilir.

\section{Nitel Bulgular}

Çalışmada, dijital hikayelerin olumlu ve olumsuz yönlerini belirlemek, öğrencilerin dijital hikâye oluşturma sürecindeki kazanımlarını ve zorlandıkları noktaları belirlemek amacı ile görüşmeler gerçekleştirilmiştir. Yapılan görüşmelerde; dijital hikâye oluşturma süreçlerinin olumlu ve olumsuz yönlerini, bu sürecin diğer öğrenme etkinliklerinden farklı yönlerini ve oluşturulan ortamların kullanılabilirliklerini belirlemeye yönelik sorular yer almıştır. Nitel bulgular görüşme soruları temel alınarak sunulmuştur. 


\section{Dijital hikâye oluşturma süreçlerinin olumlu ve olumsuz yönleri}

Deney grubundaki öğrencilere öncelikle, "Laboratuvar uygulama dersinde uyguladıkları dijital hikâye oluşturma sürecine ve ortamına yönelik görüşleriniz nelerdir?" sorusu yöneltilmiştir. Yapılan görüşmeler sonucunda, öğrenciler dijital hikâye oluşturma sürecinin olumlu ve olumsuz yönlerini Tablo 9'da görüldüğğü biçimde belirtmişlerdir.

Tablo 9. Dijital Hikâye Oluşturma Sürecinin Olumlu ve Olumsuz Yönleri

\begin{tabular}{|c|c|c|c|}
\hline & & $\begin{array}{l}\text { Olumlu } \\
\text { Yönleri }\end{array}$ & $\begin{array}{l}\text { Olumsuz } \\
\text { Yönleri }\end{array}$ \\
\hline \multirow{7}{*}{$\begin{array}{l}\text { Öğrenme süreci ile } \\
\text { ilgili }\end{array}$} & Zamanı etkili kullanma & 14 & 6 \\
\hline & Güdülenmeyi arttırma & 13 & 3 \\
\hline & Öğrenmeyi kalıcı hale getirme & 11 & \\
\hline & Öğrenmeyi kolaylaştırma & 10 & \\
\hline & Tekrar etme olanağı sunma & 9 & \\
\hline & Derse olan ilgili arttırma & 8 & 4 \\
\hline & İşbirlikçi çalışmaları destekleme & 6 & \\
\hline \multirow[t]{6}{*}{ Teknoloji kullanımı } & Bilgi arama ve bilgiye erişim becerisi kazandırma & 17 & 3 \\
\hline & İnternet kullanım becerisi kazandırma & 12 & 3 \\
\hline & $\begin{array}{l}\text { Verileri düzenleme becerisi kazandırma (Fotoğraf, video } \\
\text { gibi) }\end{array}$ & 8 & \\
\hline & Verileri paylaşma becerisi kazandırma & 8 & 1 \\
\hline & Web 2.0 uygulamalarını kullanım becerisi kazandırma & 6 & \\
\hline & Bilgisayar kullanım becerisini arttırma & 4 & 4 \\
\hline
\end{tabular}

Tablo 9 incelendiğinde öğrencilerin dijital hikâye etkinliği boyunca öğrenme süreci ve teknoloji kullanımı ile ilgili hem olumlu hem de olumsuz düşüncelere sahip olduğu görülmektedir. Dijital hikâyelerin öğrencilerin öğrenme sürecine katkısı ile ilgili olarak öğrenciler en fazla süreç içinde zamanı etkili kullanma becerisi kazandıklarını $(N=14)$, güdülenmelerinin arttığını ( $N=13)$, öğrenmelerinin daha kalıcı hale geldiğini $(\mathrm{N}=11)$ ve dijital hikâyeler sayesinde içeriği daha kolay öğrendiklerini $(\mathrm{N}=10)$ belirtmişlerdir. Bunlar dışında pek çok öğrenci dijital hikâyelerin kendilerine tekrar etme olanağı sunduğunu $(\mathrm{N}=9)$, derse olan ilgilerini arttırdığını $(\mathrm{N}=8)$ ve işbirlikçi çalışmalarını desteklediğini $(N=6)$ vurgulamıştır.

Öğrenme sürecindeki olumlu etkilerine karşın bazı öğrenciler dijital hikâyelerin olumsuz yönlerini de dile getirmişlerdir. Örneğin öğrenciler, dijital hikâye oluşturma sürecinde en fazla zamanı etkili kullanma sorunu yaşamıştır $(\mathrm{N}=6)$. Bazı öğrenciler ise bu uygulamanın derse olan ilgileri üzerinde olumlu bir etkisinin olmadığını, hatta yaşanılan teknik sorunlar nedeni ile uygulama sürecinde derse olan ilgilerinin azaldığını belirtmiştir $(\mathrm{N}=4)$. Dijital hikâyelerin öğrencilerin öğrenme sürecine etkisi ile ilgili olarak bazı öğrenciler aşağıdaki açıklamalarda bulunmuştur:

"Bence hikâye geliştirme sürecinde bilgiler daha kalıcı oldu ve bu uygulama derse daha kolay adapte olmamızı sağladı." (K14)

"Derste daha istekli olmamızı sağladı, çünkü derste sürekli aktif halde olduğumuz için dersin daha eğlenceli geçmesini sağladı. Ayrıca zamanı daha verimli kullandık. Çektiğimiz fotoğraf ve videolar bize çok yardımcı oldu." (K9)

"Hikâye geliştirme sürecinde çok eğlendim. Derse daha ilgiliydim." (K18)

"Grup çalışması konusunda bana çok yardımcı oldu. Grubumdakilerle çok iyi anlaşıyorum. Sosyalleşmemi sağladı. Ayrıca yaptığımız deneyi tekrar tekrar izleme şansına sahip oldum." (K10)

"Benim motivasyonum düştü. Ders daha sıkıcı ve boş bir hale geldi..." (K7)

Tablo 9 incelendiğinde yapılan görüşmelerde dijital hikâye geliştirme sürecinin öğrencilerin teknoloji kullanım becerileri üzerindeki etkisi belirlenmiştir. Öğrenciler dijital hikâye geliştirme uygulaması ile süreçte en fazla bilgiyi arama ve bilgiye erişim becerisi $(\mathrm{N}=17)$, interneti etkili kullanma becerisi $(\mathrm{N}=11)$ ve verileri düzenleme ve verileri paylaşma becerisi elde ettiklerini $(\mathrm{N}=8)$ belirtmişlerdir. Bunlar dışında dijital hikâye geliştirmenin, Web 2.0 
uygulamalarını kullanım becerisi $(\mathrm{N}=4)$ ve bilgisayar kullanım becerisi $(\mathrm{N}=4)$ kazandırdığı da dile getirilmiştir. Öte yandan, dijital hikâye geliştirme sürecinde öğrencilerin teknolojinin kullanımı boyutunda yaşadıkları sorunlar da bulunmaktadır. Tablo 9 incelendiğinde öğrencilerin dijital hikâye geliştirme sürecinde en fazla bilgisayar kullanımı ile ilgili $(\mathrm{N}=4)$, bilgiyi arama ve bilgiye erişim ile ilgili $(\mathrm{N}=3)$ ve verileri paylaşma ile ilgili sıkıntılar yaşadıkları görülmektedir. Dijital hikâyelerin öğrencilerin teknoloji kullanımına etkisi ile ilgili olarak bazı öğrenciler aşağıdaki açıklamalarda bulunmuşlardır.

"Ben kısa film yapmayı, blog oluşturmayı daha kaliteli fotoğraf ve video çekmeyi öğrendim."(K4)

"Teknolojileri kullanma internette aktif olma becerilerimi geliştirdim." (K12)

“...Verileri atarken biraz sıkıntı oldu." (K13)

\section{Dijital hikâyelerin diğer ders içi etkinliklerden farklı yönleri}

i̇kinci araştırma sorusunda öğrencilere; "Dijital hikâye etkinliklerinin diğer ders içi etkinliklerinden farklı yönleri nelerdir?" sorusu sorulmuştur. Öğrencilerin bu sorulara verdikleri yanıtlar Tablo 10'da yer almaktadır.

Tablo 10. Dijital Hikâye Etkinliklerinin Diğer Ders içi Etkinliklerden Farklı Yönleri

\begin{tabular}{ll}
\hline Farklı Yönler & N \\
\hline Eğlenceli olma & 15 \\
Teknolojik ortam sunma & 14 \\
ilgi çekici olma & 4 \\
Daha kalıcı öğrenme sağlama & 4 \\
Görsel destek sunma & 3 \\
Daha fazla tekrar olanağı sağlama & 1 \\
Toplam & 21 \\
\hline
\end{tabular}

Tablo 10 incelendiğinde öğrencilerin dijital hikâye etkinliğinin pek çok yönden diğer etkinliklerden farklı olduğunu söyledikleri görülmektedir. Özellikle bu uygulamanın eğlenceli olduğunu ( $N=15)$, teknolojik destekli ortam sunduğunu $(N=14)$, ilgi çekici olduğunu $(N=4)$ ve daha kalıcı öğrenme sağladığı $(N=4)$ belirtilmiştir. Konu ile ilgili olarak bazı öğrenciler şu açıklamalarda bulunmuşlardır:

"Teknolojinin de içinde olması en büyük farkı. Teknolojinin içinde bulunması daha çok dikkat çekiyor." (K3)

"Daha ilgi çekici ve daha eğlenceli." (K18)

\section{Dijital hikâye geliştirmenin ve hikâye geliştirme ortamının kullanılabilirliği}

Dördüncü görüşme sorusunda öğrencilere; "Dijital hikâye geliştirmenin ve hikâye geliştirme ortamının etkililik, verimlilik ve çekicilik boyutlarında kullanılabilirliğine yönelik görüşleriniz nedir?" sorusu yöneltilmiştir. Öğrencilerin bu soruya verdikleri yanıtlar Tablo 11'de yer almaktadır.

Tablo 11. E-Hikâye Web Sitesinin Kullanılabilirliğine ilişsin Görüşler

\begin{tabular}{lll}
\hline $\begin{array}{l}\text { Kullanılabilirlik } \\
\text { Görüşleri }\end{array}$ & & \\
\hline Verimlilik & Olumlu Yönler & Olumsuz Yönler \\
Çekicilik & 12 & \\
Etkililik & 10 & 3 \\
Toplam & 5 & 3 \\
\hline
\end{tabular}


Tablo 11 incelendiğinde, öğrencilerin kolay ve hızlı bir biçimde erişmek istedikleri içeriklere ulaşabilmeleri ve işlemlerini gerçekleştirebilmeleri nedeniyle oldukça verimli buldukları görülmektedir $(\mathrm{N}=12)$. Ayrıca öğrencilerin bu uygulamalardan hoşlandıkları, bu uygulama ile birlikte ilgilerinin ve güdülenmelerini arttığı belirlenmiştir ( $N=10)$. Öte yandan sadece 3 öğrenci içeriklere erişebilme ya da işlemlerini doğru bir şekilde yapabilme noktasında dijital hikâyeleri etkili bulmadığını belirtmiştir. Kullanılabilirlik ile ilgili olarak bazı öğrenciler şöyle söylemiştir:

"Kullanımı gayet kolay ve anlaşılabilir web sitesidir." (K9)

"Kullanımı çok kolay. Rahat erişim var. Anlaşılması daha kolay resim ve videolar sayesinde." (K18)

\section{Tartışma, Sonuçlar ve Öneriler}

Bu araştırmanın amacı Web 2.0 teknolojileri ile desteklenmiş dijital hikâye geliştirme ortamını laboratuvar uygulama dersinde kullanan biyoloji öğretmeni adaylarının, bu süreç sonundaki akademik başarıları, sayısal yetkinlik durumları ve sorgulama becerilerinde anlamlı bir farklıık olup olmadığını belirlemektir. Ayrıca bu çalışmada biyoloji öğretmen adaylarının dijital hikaye geliştirme ortamına yönelik görüşlerinin belirlenmesi de bir diğer amaç olarak belirlenmiştir.

Bu amaçlar doğrultusunda toplanan veriler analiz edilmiş ve şu sonuçlar elde edilmiştir: Web 2.0 teknolojileri ile desteklenmiş dijital hikâye geliştirme ortamını laboratuvar uygulama dersinde kullanan biyoloji öğretmeni adaylarının; dijital hikayeler sayesinde akademik başarıları, sayısal yetkinlikleri ve sorgulama becerilerinin arttığı belirlenmiştir. Buna ek olarak araştırmanın nitel boyutu ile dijital hikayelerin öğrenme süreci ve teknoloji kullanımı boyutlarında öğrencilere çok fazla olumlu etkisinin olduğunu belirlenmiştir. Dijital hikayelerin öğrenciler üzerindeki olumlu etkileri ise; öğrenmeyi kolaylaştırma, kalıcılığı arttırma, işbirliğini destekleme, öğrencilerin ilgilerini ve güdülenmelerini arttırma, sorgulama becerilerini geliştirme, tekrar etme olanı sunma ve dersin eğlenceli hale gelmesini sağlama biçiminde sıralanabilir.

Alanyazın incelendiğinde, dijital hikâyelerin öğrenme çevresini zenginleştirdiği, öğrencilerin akademik başarısını, güdülenmelerini, ilgilerini ve derse yönelik tutumlarını arttırdığı, işbirlikli öğrenmeleri desteklediği, sorgulama becerisini geliştirdiği ve kalıı öğrenmeler sağladığı pek çok araştırmada da ortaya konulmaktadır (Clarke ve Adam, 2011; Hung vd., 2012; Lowenthal ve Dunlap, 2010; Robin, 2008; Sadik, 2008; Xu, Park ve Baek, 2011; Yang ve Wu, 2012). Örneğin, Lowenthal ve Dunlap (2010) araştırmalarında dijital hikayelerin özellikle sağladığı işbirlikli öğrenme ortamı ile birlikte bir yandan bilginin yapılandırmasını geliştirdiğini, öte yandan öğrenme ortamında problem çözme becerilerinin gelişmesinde ve öğrenme başarıların artmasında etkili olduğunu belirlemişlerdir. Ayrıca, deney grubu öğrencilerinin eğitsel çıktıları ve akademik başarılarında ki artış; akademik uğraşı durumlarının artması ve teknoloji kullanım süreçlerinin akademik olarak işbirlikli öğrenme ortamları ile paylaşımlarından kaynaklı olduğu da söylenebilir. Benzer bir biçimde Hughes (2005) ve Yang ve Wu (2012) da dijital hikayelerin, öğrencilerin akademik başarılarını arttırdığını, eleştirel yansıma becerilerini ve sorgulama becerilerini geliştirdiğini ortaya koymuşlardır. Dijital hikayelerin öğrencilerin başarısı ile üst düzey düşünme becerileri üzerindeki bu olumlu etkileri, pek çok farklı alanda ve süreçte öğrenmeleri desteklemek için dijital hikayelerin kullanılabileceğini göstermektedir.

Öte yandan, yapılan araştırmada dijital hikayelerin öğrencilerin teknoloji yeterliği ve sayısal yetkinlikleri üzerinde de oldukça etkili olduğu belirlenmiştir. Yapılan araştırmada elde edilen nicel ve nitel bulgular sonucunda, öğrencilerin bilgiyi arama, sorgulama, düzenleme ve paylaşma becerileri ile birlikte, bilgisayarı ve internet uygulamalarını etkili kullanımlarının arttığı da ortaya konulmuştur. Alanyazında da dijital hikaye geliştirme süreçlerinin öğrencilerin teknoloji okur-yazarlık becerilerini ve sayısal yetkinliğini arttığına yönelik bulgular dikkati çekmektedir (Lowenthal ve Dunlap, 2010; Gyabak ve Godina, 2011; Røkenes, 2016). Örneğin, Gyabak ve Godina (2011), araştırmalarında dijital hikâye geliştirme sürecinde öğrencilerin teknoloji bilgilerinin ve teknoloji kullanımı konusundaki yetkinliklerinin arttığını belirlemişlerdir. Røkenes (2016) ise, araştırması sonucunda dijital hikayeler sayesinde öğrencilerin bilgiyi daha iyi yapılandırdıklarını ve süreç sonunda sayısal yeterlik kazandıklarını ortaya koymuştur. Öğrencilerin dijital hikâye geliştirme sürecinde kazandığı tüm bu beceriler; dijital hikayelerin çağın kaliteli ve nitelikli birey arayışına cevap olabilecek eğitim ortamını sağlaması ve öğrencilerin gerek pedagojik gerekse teknik açıdan kazanımları elde etmesi bağlamında önem taşımaktadır. Bu nedenle gelecekteki öğretim ortamlarında bu yaklaşımın kullanıldığı öğrenme ortamlarının artması gerektiği düşünülmektedir.

Sonuç olarak bu çalışma fen eğitiminde öğrenim gören öğretmen adayları ile gerçekleştirilmiş ve dijital hikâye oluşturma sürecinde öğretmen adaylarının teknoloji kabul ve kullanım durumları ile bilgi ve iletişim teknolojilerinin 
derse entegrasyonunun başarılı bir şekilde oluştuğu görülmüştür. Tüm bu bulgular göz önünde bulundurulduğunda ise şu önerilerde bulunulabilir:

- Yalnızca lisans düzeyinde değil diğer sınıf seviyelerinde de dijital hikâye kullanımının öğrencilerin başarıları ve üst düzey düşünme becerileri üzerindeki etkisi araştırılabilir.

- Yalnızca fen bilimleri alanında değil farklı alanlarda ve farklı derslerde öğretmen ve öğrencilerin bu şekilde çalışmalar yapması ve farklı eğitsel çıktılara olan etkisi araştırılabilir.

- Öğretmen adaylarının web içerik bilgilerinin iyileştirilebilmesi ve dijital hikayeler geliştirebilmeleri için hizmet içi ve uzaktan eğitim seminerlerine alınması ya da fakülteden mezun olmadan önce hizmet öncesi yaşamlarında, bu bilgi becerileri kazanmalarını sağlayan ders ve etkinliklerin planlanarak öğretmen adaylarına sunulması sağlanabilir.

- Bu tür uygulama araştırmaları ile öğretmenlerin, öğretmen adaylarının ve öğrencilerin gelişim ve değişim süreçleri gözlenerek eksiklikler tespit edilebilir ve bu eksikliklerin giderilmesi için eğitim-öğretim planlamaları yapılabilir.

\section{Kaynakça}

Akkoyunlu, B., \& Soylu, Y. (2010). Öğretmenlerin sayısal yetkinlikleri üzerine bir çalışma. Türk Kütüphaneciliği, 24(4), 748-768.

Akkoyunlu, B., Soylu, M. Y., \& Çağlar, M. (2010). Üniversite öğrencileri için "Sayısal Yetkinlik Ölçeği" geliştirme çalışması. Hacettepe Üniversitesi Eğitim Fakültesi Dergisi, 39(39), 10-19.

Aldan-Karademir, Ç. A., \& Saracaloğlu, A. S. (2013). Sorgulama becerileri ölçeği'nin geliştirilmesi: geçerlik ve güvenirlik çalışması. Asian Journal of Instruction, 1(2), 56-65.

Aydoğmuş, E., Sarıkoç, A. ve Berber, N. C. (2010). Lise 2 Fizik Dersi İş-Enerji Konusunun Öğretiminde 5E Modelinin Öğrenci Başarısına ve Tutumuna Etkisinin Araştırılması. Selçuk Üniversitesi Ahmet Keleşoğlu Eğitim Fakültesi Dergisi, 29, 83-94.

Barnes, K., Marateo, R. C., \& Ferris, S. P. (2007). Teaching and learning with the net generation. Innovate: Journal of Online Education, 3(4), 1.

Bhattacherjee, A., \& Premkumar, G. (2004). Understanding changes in belief and attitude toward information technology usage: A theoretical model and longitudinal test. MIS quarterly, 229-254.

Chu, S. K. W., Tse, S. K., \& Chow, K. (2011). Using collaborative teaching and inquiry project-based learning to help primary school students develop information literacy and information skills. Library \& Information Science Research, 33(2), 132-143.

Chung, S.K. (2007). Art education technology: Digital storytelling. Art Education, 60(2), 17-22.

Clarke, R., \& Adam, A. (2011). Digital storytelling in Australia: Academic perspectives and reflections. Arts and Humanities in Higher Education, 11 (1-2), 157-176.

Creswell, J. W., and Plano-Clark, V. L. (2007). Designing and conducting mixed methods research. Thousand Oaks, CA: Sage.

Dijk, J. (2003). A Framework for digital divide research. Journal of Communication/Revue de Communication Electronique, 12, 1- 2.15 Ocak 2019 tarihinde http://www.cios.org/www/ejc adresinden erişildi.

Dreon, O., Kerper, R. M., \& Landis, J. (2011). Digital storytelling: A tool for teaching and learning in the YouTube generation. Middle School Journal, 42(5), 4-10.

Dupain, M., \& Maguire, L. (2005). Digital story book projects 101: How to create and implement digital storytelling into your curriculum. Paper presented at the 21st Annual Conference on Distance Teaching and Learning.

Ediger, M. (2001). Assessing: Inquiry Learning in Science. 02.02.2017 tarihinde http://files.eric.ed.gov/fulltext/ED454274.pdf adresinden erişilmiştir. 
Gyabak, K., \& Godina, H. (2011). Digital storytelling in Bhutan: A qualitative examination of new media tools used to bridge the digital divide in a rural community school. Computers \& Education, 57(4), 2236-2243.

Haugerud, T. (2011). Student teachers learning to teach: The mastery and appropriation of digital technology. Nordic Journal of Digital Literacy, 6(04), 226-238.

Heo, M. (2009). Digital storytelling: An empirical study of the impact of digital storytelling on pre-service teachers' selfefficacy and dispositions towards educational technology. Journal of Educational Multimedia and Hypermedia, 18(4), 405.

Heo, M. (2011). Improving technology competency and disposition of beginning pre-service teachers with digital storytelling. Journal of Educational Multimedia and Hypermedia, 20(1), 61.

Hsieh, S. W., Jang, Y. R., Hwang, G. J., \& Chen, N. S. (2011). Effects of teaching and learning styles on students' reflection levels for ubiquitous learning. Computers \& Education, 57(1), 1194-1201.

Hughes, J. (2005). The role of teacher knowledge and learning experiences in forming technology-integrated pedagogy. Journal of Technology and Teacher Education, 13(2), 277-302

Hung, C. M., Hwang, G. J., \& Huang, I. (2012). A Project-based digital storytelling approach for improving students' learning motivation, problem-solving competence and learning achievement. Educational Technology \& Society, 15(4), 368-379.

Judge, S., Puckett, K., \& Cabuk, B. (2004). Digital equity. Journal of Research on Technology in Education, 36, 383-396.

Kahraman, Ö. (2013). Dijital hikâyecilik metoduyla hazırlanan öğretim materyallerinin öğrenme döngüsü giriş aşamasında kullanılmasının fizik dersi başarısı ve motivasyonu düzeyine etkisi. Yayımlanmamış Doktora Tezi. Balıkesir Üniversitesi, Balıkesir.

Kajder, S. B. (2004). Enter here: Personal narrative and digital storytelling. English Journal, 64-68.

Karataş, S., Bozkurt, Ş. B., \& Hava, K. (2016). The perspective of history pre-service teachers' towards the use of digital storytelling in educational environments Tarih öğretmeni adaylarının öğretim ortamlarında dijital hikâye anlatımı etkinliğinin kullanımına yönelik görüşleri. Journal of Human Sciences, 13(1), 500-509.

Kocaman-Karoğlu, A. (2015). Öğretim sürecinde hikâye anlatmanın teknolojiyle değişen doğası: dijital hikâye anlatımı. Eğitim Teknolojisi Kuram ve Uygulama, 5(2), 89-106.

Kurudayıoğlu, M., \& Bal, M. (2014). Ana dili eğitiminde dijital hikâye anlatımlarının kullanımı. Sakarya Üniversitesi Eğitim Fakültesi Dergisi, (28), 74-95.

Lee, M. H., \& Tsai, C. C. (2010). Exploring teachers' perceived self efficacy and technological pedagogical content knowledge with respect to educational use of the World Wide Web. Instructional Science, 38(1), 1-21.

Lowenthal, P. (2009) Digital Storytelling in Education. In J. Hartley and K. McWilliam (Eds), Story Circle: Digital Storytelling around the World. Wiley-Blackwell, Oxford, UK.

Lowenthal, P. R., \& Dunlap, J. C. (2010). From pixel on a screen to real person in your students' lives: Establishing social presence using digital storytelling. The Internet and Higher Education, 13(1), 70-72.

Malita, L., \& Martin, C. (2010). Digital storytelling as web passport to success in the 21st century. Procedia-Social and Behavioral Sciences, 2(2), 3060-3064.

McGinn, M. K., \& Roth, W. M. (1999). Preparing students for competent scientific practice: Implications of recent research in science and technology studies. Educational Researcher, 28(3), 14-24.

Meadows, D. (2003). Digital storytelling: Research-based practice in new media. Visual Communication, 2(2), 189-193.

MEB (2004). Fen ve teknoloji dersi programı, ilköğretim 4.-5. sınıf. Ankara.

Morgan, H. (2014). Using digital story projects to help students improve in reading and writing. Reading Improvement, 51(1), 20-26.

Nelson, J., Christopher, A., \& Mims, C. (2009). TPACK and Web 2.0: Transformation of teaching and learning. Tech Trends, 53(5), 80-85. 
Niemi, H., Harju, V., Vivitsou, M., Viitanen, K., Multisilta, J., \& Kuokkanen, A. (2014). Digital storytelling for 21st-century Skills in virtual learning environments. Creative Education, 5, 657-671.

Ohler, J. (2006). The world of digital storytelling. Educational Leadership, 63(4), 44-7.

Ohler, J. (2008). Digital storytelling in the classroom: New media pathways to literacy, learning, and creativity. Thousand Oaks, CA: Corwin Press.

ÖSYM (2018). 2018 YKS Değerlendirme raporu. 12.1.2019 tarihinde https://dokuman.osym.gov.tr/pdfdokuman/2018/GENEL/YKSDegrapor06082018.pdf adresinden erişilmiştir.

Özpınar, İ. (2017). Matematik Öğretmeni Adaylarının Dijital Öyküleme Süreci ve Dijital Öykülerin Öğretim Ortamlarında Kullanımına Yönelik Görüşleri. Bartın Üniversitesi Eğitim Fakültesi Dergisi, 6(3), 1189-1210.

Prensky, M. (2001). Digital natives, digital immigrants. On the horizon, 9(5), 1-6.

Robin, B. (2006). The educational uses of digital storytelling. In C. Crawford et al. (Eds.), Proceedings of Society for Information Technology \& Teacher Education International Conference 2006 (pp. 709-716). Chesapeake, VA: AACE.

Robin, B. R. (2008). Digital storytelling: A powerful technology tool for the 21st century classroom. Theory into practice, 47(3), 220-228.

Røkenes, F. M. (2016). Digital storytelling in teacher education: A meaningful way of integrating ICT in ESL teaching. Acta Didactica Norge, 10(2), 311-328.

Sadik, A. (2008). Digital storytelling: A meaningful technology-integrated approach for engaged student learning. Educational technology research and development, 56(4), 487-506.

Sancar-Tokmak, H., Sürmeli, H. \& Özgelen, S. (2014). Preservice science teachers'perceptions of their TPACK development after creating digital stories. International Journal of Environmental and Science Education, 9(3), 247-264.

Smeda, N., Dakich, E., \& Sharda, N. (2012). Digital storytelling with Web 2.0 tools for collaborative learning. A. Okada (Ed.). Collaborative Learning 2.0: Open Educational Resources: Open Educational Resources, (pp.145-163). IGI Global.

Thompson, J. (2007). Is Education 1.0 ready for Web 2.0 students? Innovate: Journal of Online Education, 3(4), 1-6.

Ulum, E., \& Ercan-Yaman, F. (2018). Fen bilimleri dersinde dijital hikaye hazırlamanın ders başarısı düşük ve bilgisayarla fazla vakit geçiren öğrenciler üzerindeki etkisinin incelenmesi. Necatibey Eğitim Fakültesi Elektronik Fen ve Matematik Eğitimi Dergisi, 12(2), 306-335.

Uslupehlivan, E., Erden, M. K., \& Cebesoy, Ü. B. (2017). Öğretmen adaylarının dijital öykü oluşturma deneyimleri. Uşak Üniversitesi Sosyal Bilimler Dergisi, 10, 1-22.

Ware, P. D. (2006). From sharing time to showtime! Valuing diverse venues for storytelling in technology-rich classrooms. Language Arts, 84(1), 45-54.

Weis, T. M., Benmayor, R., O'Leary, C., \& Eynon, B. (2002). Digital technologies and pedagogies. Social Justice, 29(4), 153-167.

Xu, Y., Park, H., \& Baek, Y. (2011). A new approach toward digital storytelling: An activity focused on writing selfefficacy in a virtual learning environment. Educational Technology \& Society, 14(4), 181-191.

Yang, Y. T. C., \& Wu, W. C. I. (2012). Digital storytelling for enhancing student academic achievement, critical thinking, and learning motivation: A year-long experimental study. Computers \& Education, 59(2), 339-352.

Hess, M. E. (2014). A new culture of learning: Digital storytelling and faith formation. Dialog: A Journal of Theology, 53(1):12-22. DOI: 10.1111/dial.12084.

Matthews, J. (2014). Voices from the heart: The use of digital storytelling in education. Community Practitioner, 87(1), 28-30.

Toki, E. I. ve Pange, J. (2014). Ict use in early childhood education: Storytelling. Bridges / Tiltai, 66(1), 183-192. 


\section{Ek}

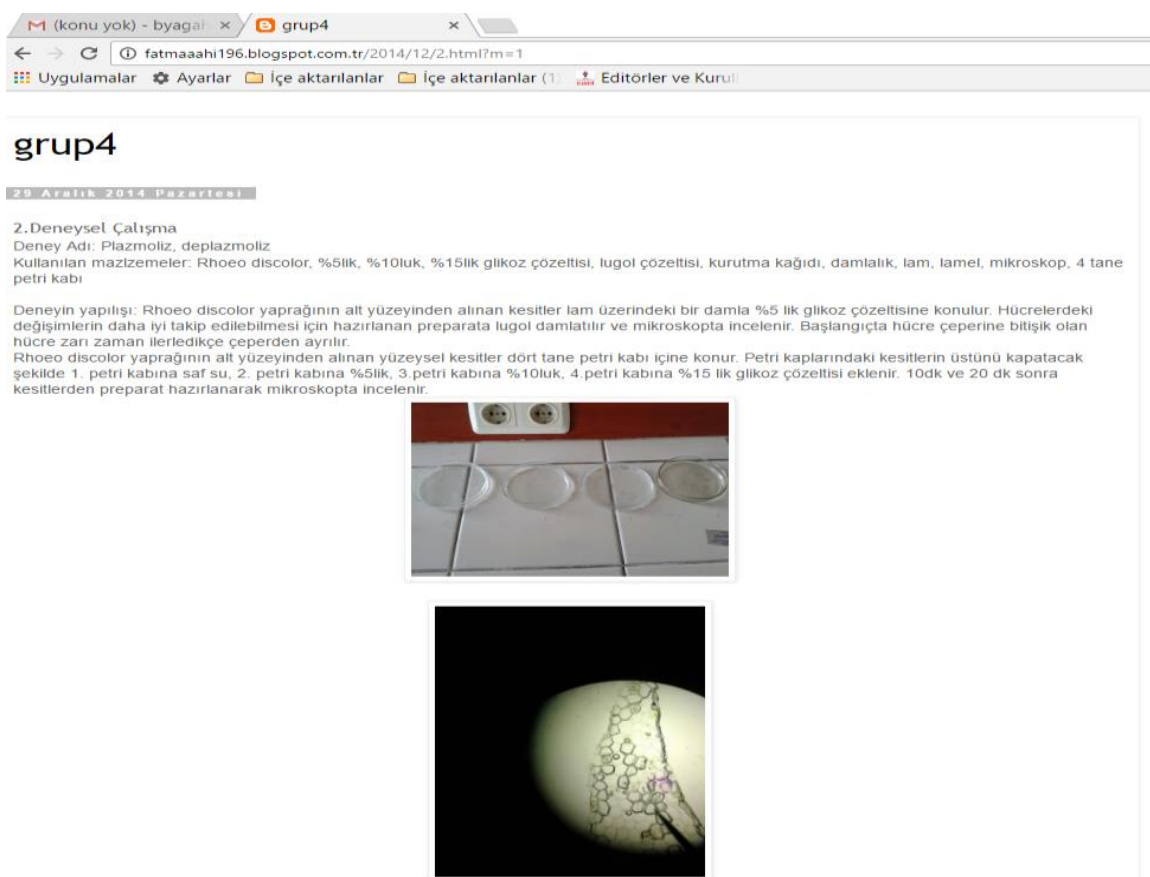

\section{Şekil 1: Grup Deney Çalışmalarının Blog Paylaşımları (Metin Ve Resim Anlatımı)}

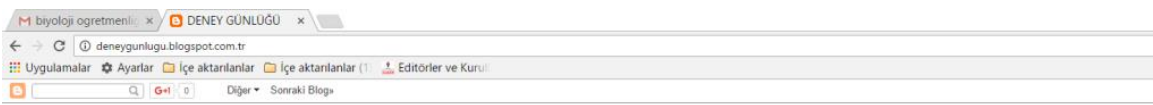

DENEY GÜNLÜĞÜ

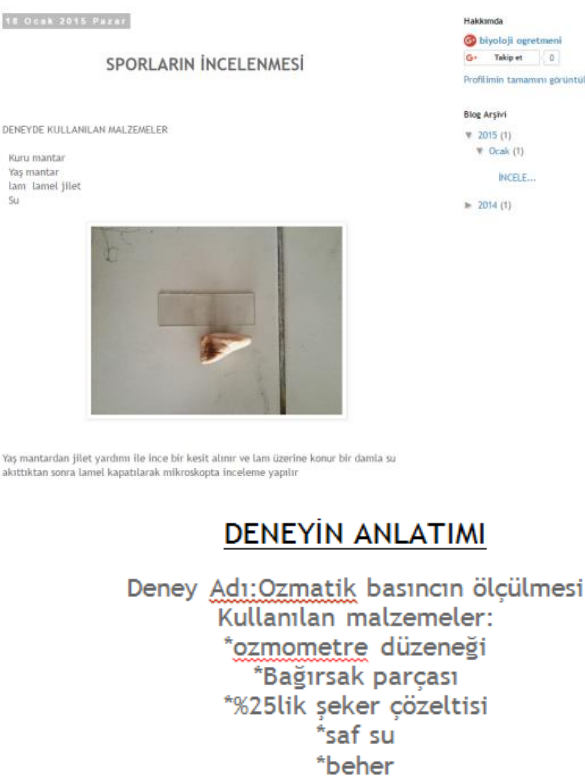

Deneyin hazırlanısı: Islatılıp yumușatılmıs bağırsak parçası huninin ağzına sıkıca bağlanır. Ozmometre hunisi \%25lik seker çözeltisiyle doldurulur. Huni bir statif yardımıla basasağı gelecek șekilde içerisinde saf su bukunan beherin içerisine yerleștirilir. Beșer dakikalık aralıklarla ozmometre hunisinin borusundaki su seviyesi ișaretlenerek ölçüumler yapılır. 

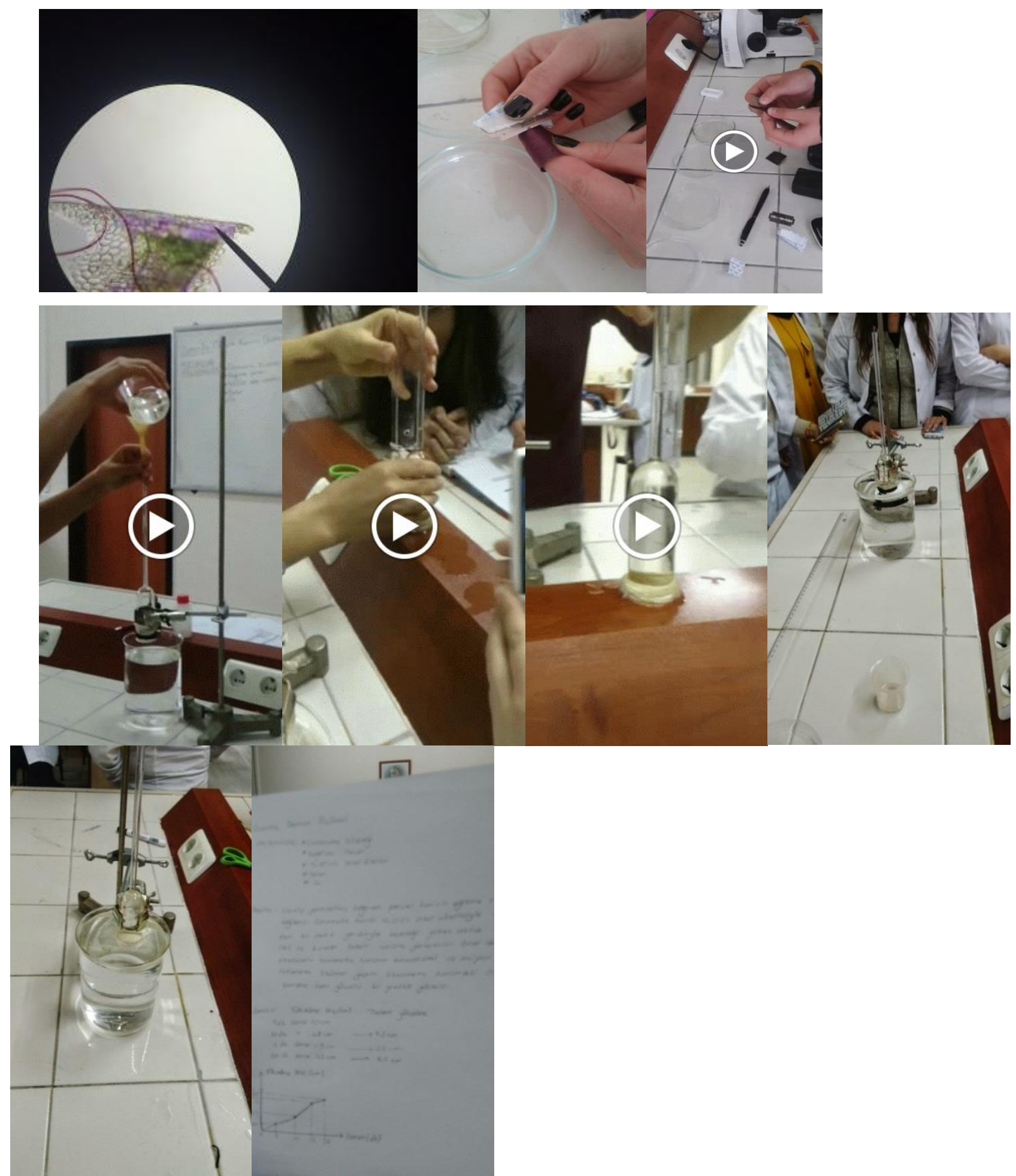

Şekil 2: Grup Deney Çalışmalarının Blog Paylaşımları (Metin Ve Video Anlatımı) 


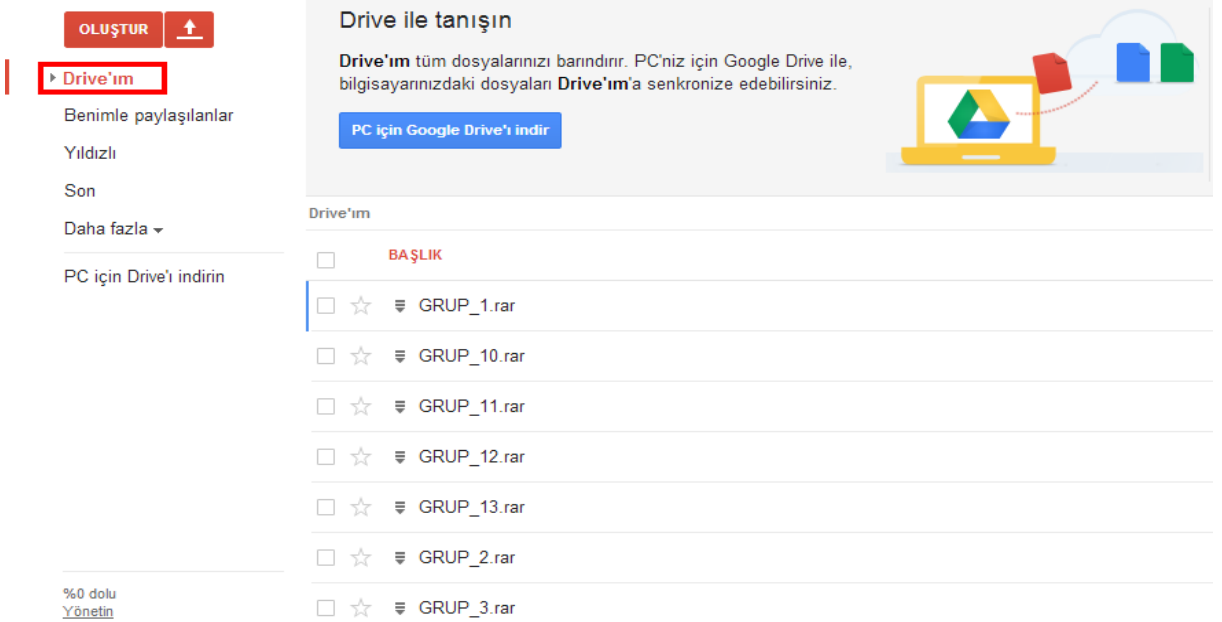

Şekil 3: Google Drive Grupların Paylaşımları

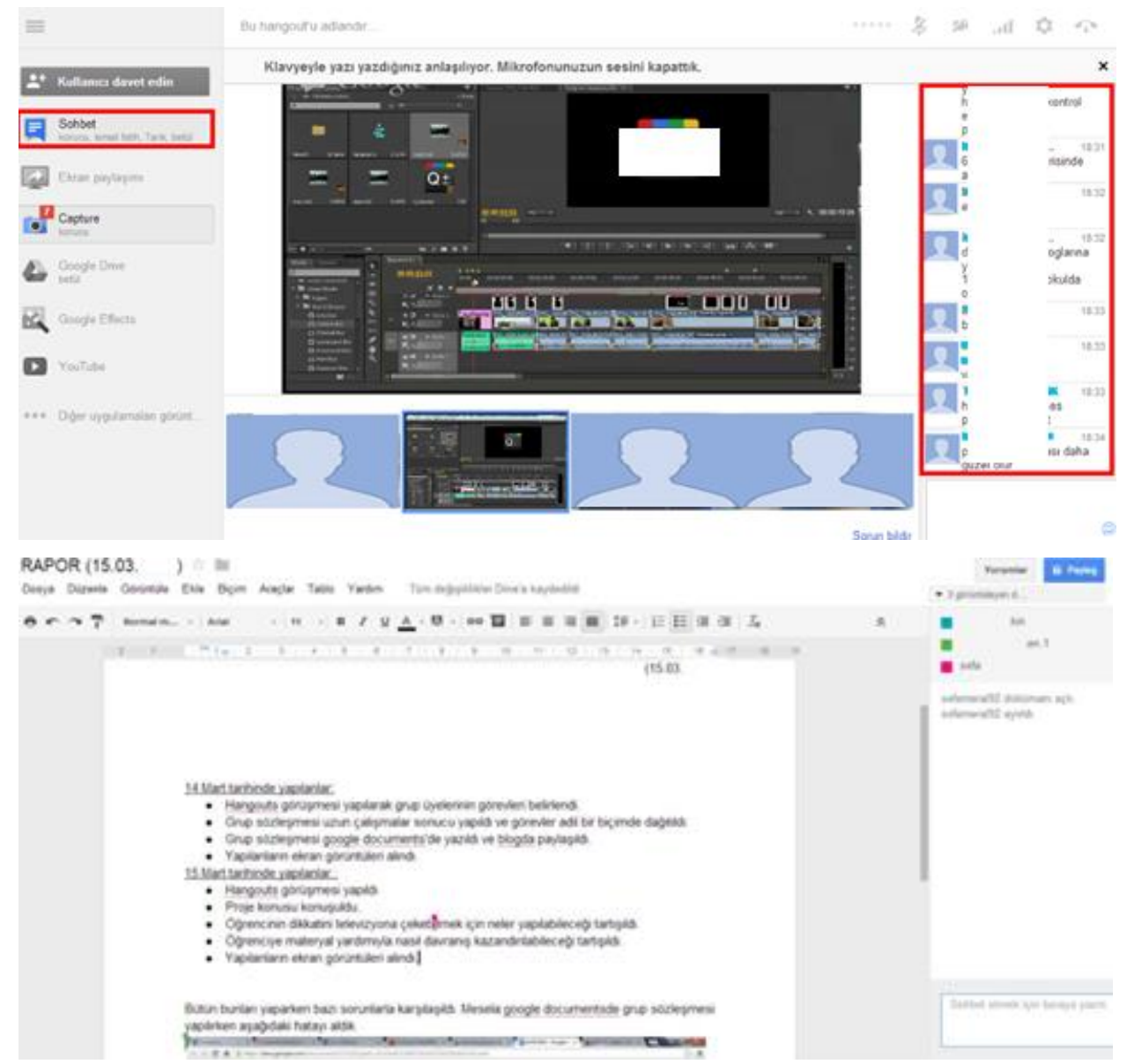

Şekil 4: Grupların Google Hangout Ve Google Document Paylaşımları 